IFAS Extension

\title{
Florida Crop/Pest Management Profile: Watermelon ${ }^{1}$
}

\author{
Wael M. Elwakil and Mark A. Mossler²
}

\section{Production Facts}

- In 2010, Florida ranked first nationally in watermelon production, accounting for $18 \%$ of the total U.S. production, $23 \%$ of the U.S. crop's total value, and $19 \%$ of the national watermelon acreage (USDA/NASS 2011a; FDACS 2012).

- Florida's cash receipts for watermelon production totaled $\$ 111.9$ million in 2010-2011. During the 2010 production season, watermelon was the state's seventh ranking vegetable crop in terms of value. Watermelon production value represented $5.6 \%$ of the total production value of all Florida vegetables (FDACS 2012).

- In 2010-2011, Florida growers planted 25,900 acres of watermelons and harvested 24,400 acres. Average yield was 31,000 pounds per acre for a total production of 756.4 million pounds. Harvested acreage during the past decade has ranged from 22,800 acres harvested in 2007 to 26,100 acres harvested in 2008 (USDA/NASS 2011a; FDACS 2012).

- In 2007, Florida had 401 farms producing watermelon. Of those, $52.6 \%$ produced watermelons on less than 5 acres, representing approximately $1 \%$ of the state's total acreage. An additional $21.9 \%$ maintained 5-49.9 acres of watermelons (representing $7.7 \%$ of acreage), 19.7\% planted 50-249.9 acres (representing approximately $46.7 \%$ of acreage), and $5.7 \%$ planted more than 250 acres of watermelons (representing $44.5 \%$ of the state's total acreage) (USDA/NASS 2009).

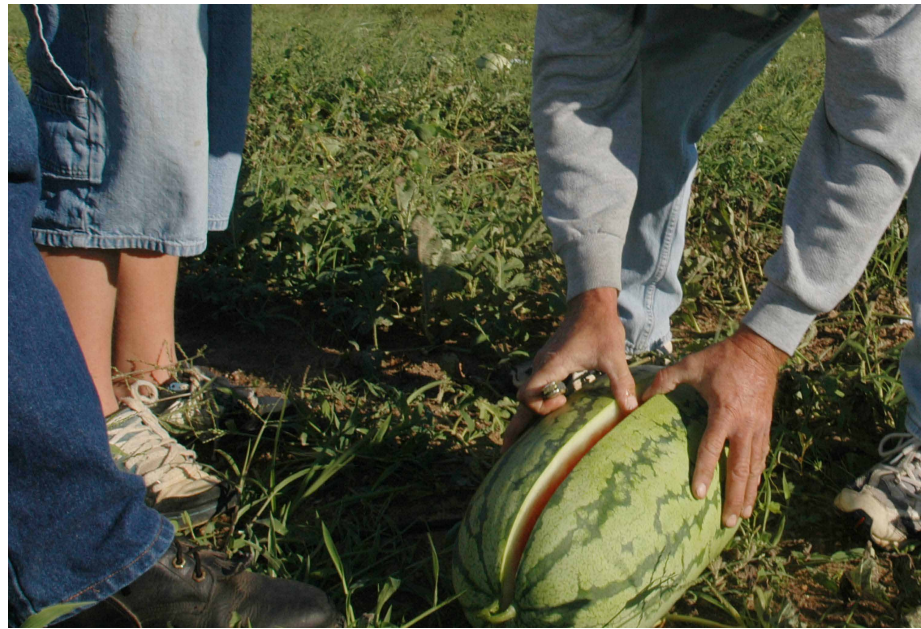

Figure 1. In 2010, Florida ranked first in the United States in watermelon production, accountting for $18 \%$ of watermelons grown in the country. Credits: UF/IFAS Communications

- Florida is the only U.S. supplier of watermelons from December to April. Florida watermelons are harvested throughout the year, although the vast majority of production is harvested from May to July (Bertelsen et al. 1994).

- Growers received $\$ 0.148$ per pound in 2011 , and during the past decade this price has ranged from $\$ 0.082$ per

1. This document is CIR1236, one of a series of the Horticultural Sciences Department, UF/IFAS Extension. Original publication date October 2000. Latest revision August 2013. Visit the EDIS website at http://edis.ifas.ufl.edu.

2. Wael M. Elwakil, doctor of plant medicine student, and Mark A. Mossler, pest management information specialist, Pesticide Information Office, Agronomy Department; UF/IFAS Extension, Gainesville, FL 32611.

The use of trade names in this publication is solely for the purpose of providing specific information. UF/IFAS does not guarantee or warranty the products named, and references to them in this publication do not signify our approval to the exclusion of other products of suitable composition. 
pound in 2002 to $\$ 0.188$ per pound in 2007 (FDACS 2012).

- Average total production costs in 2008-2009 were estimated at \$3,978 per acre for watermelons in Manatee, Florida. Production costs in southwestern Florida were $\$ 4,979$ per acre (Smith and Taylor 2011).

- Production costs can be higher in South Florida than in North Florida. But South Florida growers can enter the market early, providing them with prices up to two to three times higher than those received in North Florida (Hochmuth et al. 1997).

\section{Production Regions}

Watermelons are grown throughout Florida. The greatest production region is the north to north-central region, including Suwannee, Gilchrist, Alachua, Lake, Levy, Marion, and Sumter Counties. In 2002, this region comprised $36.6 \%$ of the harvested acreage and $26.7 \%$ of the state's watermelon-producing farms. The west-central region (including Manatee, Hardee, DeSoto, and Highlands Counties) comprised $20.5 \%$ of the acreage and $5.7 \%$ of the watermelon-producing farms in that year, while the southwest region (including Lee, Hendry, and Collier Counties) held $19.3 \%$ of the watermelon acreage and $5.5 \%$ of the farms. An additional 18\% of acreage was found in the northwest region (including Jackson, Jefferson, Santa Rosa, Washington, and Holmes Counties), containing 5.6\% of the state's watermelon-producing farms. Remaining watermelon production is distributed among 40 of the state's other counties (USDA/NASS 2009).

\section{Production Practices}

Watermelons require a long, warm growing season and grow best under temperatures of $70^{\circ} \mathrm{F}-85^{\circ} \mathrm{F}\left(21^{\circ} \mathrm{C}-29^{\circ} \mathrm{C}\right)$, tolerating temperatures up to $90^{\circ} \mathrm{F}\left(32^{\circ} \mathrm{C}\right)$. The plant also tolerates high humidity (Bertelsen et al. 1994). Although watermelons are produced on a number of soil types, the crop does not do well on muck soils (Spreen et al. 1995). The optimum $\mathrm{pH}$ range for watermelons is 6.0-6.5, although the plant will tolerate soils with $\mathrm{pH}$ as low as 5 (Maynard 2003). Soil temperature also affects watermelon production. Frost easily damages seedlings, and germination is very slow when soil temperature is less than $70^{\circ} \mathrm{F}$ $\left(21^{\circ} \mathrm{C}\right)$. Watermelon growers in Florida have a planting window of only a few weeks and must balance the risk of losses from frost damage with maximizing economic returns from an early harvest (Hochmuth et al. 1997).

Both seeded and seedless watermelons are produced in Florida. Seeded watermelon varieties available in Florida

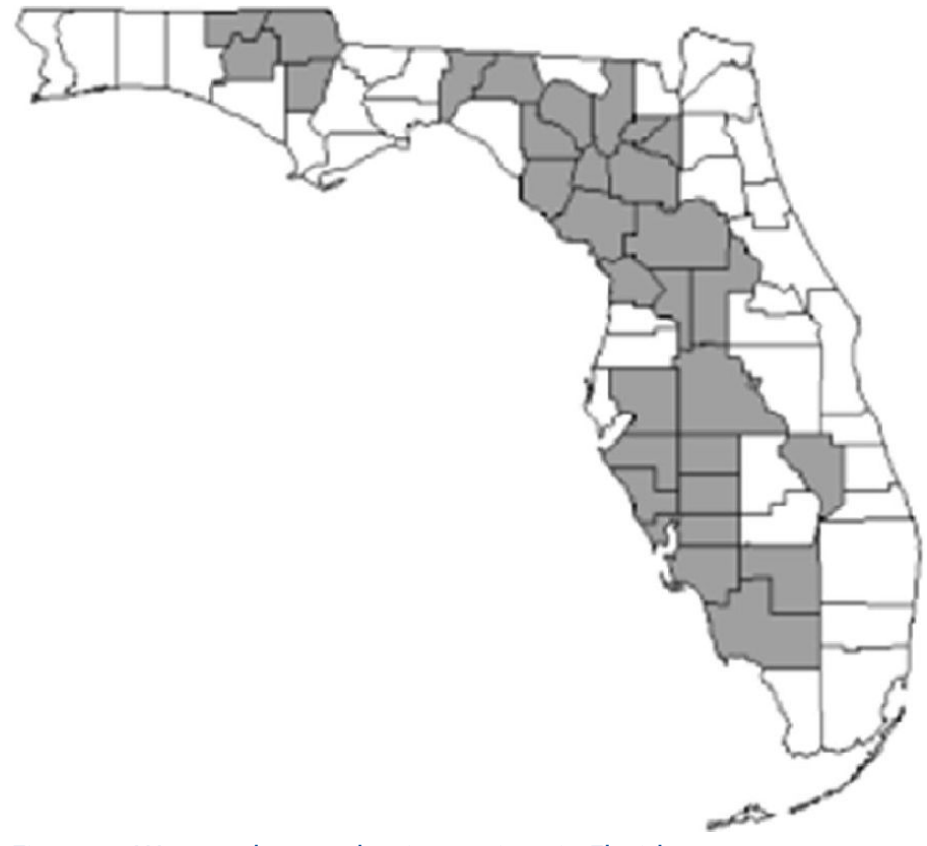

Figure 2. Watermelon production regions in Florida.

include 'Duration', 'Estrella, 'Gold Strike, 'Jamboree', 'Mardi Gras', 'Regency', 'Royal Star,' 'Royal Sweet,' 'Sangria,' 'Sentinel', 'Starbrite,' 'Stars N' Stripes', 'Summer Flavor 790, 'Summer Flavor 800', 'Summer Flavor 840', and 'Summer Flavor 900'. Seedless watermelon varieties available include 'Crisp N' Sweet', 'Crunchy Red,' 'Freedom', 'Gypsy', 'Liberty', 'Matrix,' 'Melody', 'Millionaire,' 'Olympia, 'Revolution', 'Ruby Premium, 'Sugar Coat', 'Sugar Heart', 'Sugar Crisp 85, 'Summer Sweet 5244', 'Super Seedless 7177', 'Super Seedless 7178', 'Sweet Delight', 'Sweet Polly', 'Sweet Treasure', 'Tri-X-212', 'Tri-X-313', 'Tri-X-Palomar', and 'Triton' (Olson et al. 2012). Production of seedless varieties in Florida has been increasing, particularly in North Florida (Brinen 2003). As more seedless watermelon varieties have been brought to U.S. markets, there have been parallel increases in national watermelon consumption. The popularity of seedless watermelons is expected to grow. In addition to being more convenient for the consumer, seedless varieties are sweeter and have a longer shelf life (Maynard 1996).

Seedless varieties are sterile hybrids, and the seeds are produced by crossing a normal watermelon and one that was genetically changed through chemical treatment at the seedling stage. When pollinated with normal watermelon plants, seedless plants produce only small, white undeveloped seedcoats. These are soft and tasteless and can be eaten with the watermelon flesh. The parent watermelon of a seedless plant produces only $5 \%-10 \%$ as many seeds as the normal plant, resulting in seeds that cost 5-10 times greater than seeded hybrid varieties and 10-100 times greater than standard, open-pollinated varieties. Seedless 
varieties require soil temperatures above $80^{\circ} \mathrm{F}\left(26.7^{\circ} \mathrm{C}\right)$ for germination, and both germination and seedling emergence are slower for seedless varieties (Maynard 1996; Stephens 2012).

Seedless varieties of watermelons are transplanted because of the high cost of hybrid seed. In addition, seedless varieties cannot be established by direct seeding (Bertelsen et al. 1994). As seedless watermelon production increases in Florida, the use of transplants is becoming increasingly popular (Spreen et al. 1995). Approximately half of the watermelons in Florida are currently grown from transplants (Maynard 2003). Generally, growers in the southern half of the state tend to grow transplanted watermelons on plastic mulch. In the northern and western portions of the state (starting in the Gainesville area), a wide mix of cultural practices is used. Approximately $30 \%$ of growers use direct seeding and bare ground culture, but many others (70\%) use transplants on plastic mulched beds, a practice used increasingly in North Florida (Maynard 2003; Hochmuth 2003). If plastic mulch is not used, the crop is grown on an open-bed system, particularly when the soils are likely to flood. In Florida, bed height varies from 3 to 8 inches $(7.6-20 \mathrm{~cm})$, depending on the slope and drainage of the land (Hochmuth and Elmstrom 1992).

When transplants are used, they are first grown in greenhouses and are usually field-ready in 3-5 weeks. Bare-root transplants cannot be used. Instead, transplants are grown in planter flats to maintain the root and soil ball (Hochmuth and Elmstrom 1992; Vavrina 1992). Transplanting watermelons permits earlier harvesting, particularly if used with plastic mulch (Hochmuth et al. 1997). Yields are generally higher for transplanted watermelons, and the resulting plant uniformity makes cultivation easier. Production costs for direct-seeded and transplanted watermelons were similar in a comparison of the costs and returns of both methods grown on plastic mulch in North Florida in 1995. However, transplanted watermelons had a higher profitability because of higher yields and a higher market price as a result of early harvest (Hewitt 1996). Direct-seeding also has advantages, including lower labor requirements, the availability of precision planting (which improves efficiency), and the possible production of greater vine area (which reduces sunburn) (Vavrina 1992; Hewitt 1996).

In South Florida, watermelons are primarily grown on plastic mulch as a second crop in a double-cropping system, following tomato or pepper. North Florida growers use the mulch to warm the soil, allowing them to plant earlier in the season and ship their product to market early. Using polyethylene mulch lets producers harvest earlier, and it aids in weed control and improves the efficiency of water and fertilizer use. Plastic mulch is also a requirement for soil fumigation. When plastic mulch is used, a bed press shapes a smooth bed to maximize contact between the mulch and the bed surface. Fertilizer and soil-applied pesticides are added to the bed before the mulch is laid down. Plastic mulch measuring approximately 48 inches $(122 \mathrm{~cm})$ wide is placed on beds measuring approximately 20-24 inches $(51-61 \mathrm{~cm})$ across the top. Mulch used for double-cropping needs to be able to survive two crop seasons (Spreen et al. 1995; Brinen 2003; Hochmuth and Elmstrom 1992).

If this system is used, worker activities for the season begin with laying mulch. Overall, worker activities mostly include tractor-driven operations, such as cultivation, fertilization, and laying drip tape. The only field task is shoveling dirt on the mulch to bury it, which generally requires three people on each end. A two-row plastic mulch applicator will cover about 8 acres a day. With an average-size farm of 40 acres, shovel crews would be needed approximately 40 hours ( 5 days) a year. Placing emitters on the irrigation main line requires hand labor, and one worker can cover 15-20 acres a day. Workers setting transplants (approximately 5 days for a 40-acre farm) often wear latex gloves. Workers with poles also move vines out of row middles for the lay-by fertilizer application made at mid-season.

Primary planting dates for watermelons in Florida range from December 15 to April 15. Planting extends from December 15 to March 1 in South Florida, from January 15 to March 15 in Central Florida, and from February 15 to April 15 in North Florida. A small amount of acreage scattered among South, Central, and North Florida is planted for a fall harvest (October through December) (Hochmuth et al. 1997; Olson et al. 2012).

Seeds are planted with $60-108$ inches $(152-274 \mathrm{~cm})$ between rows and $24-72$ inches $(61-183 \mathrm{~cm})$ between plants, giving a plant population of 4,356 per acre at the closest spacing. Optimum yield under irrigation is generally obtained with 84-96 inches $(213-244 \mathrm{~cm})$ between rows and 24-36 inches $(61-91 \mathrm{~cm})$ between plants. Seeds are planted at a depth of 1.5-2 inches $(3.8-5.1 \mathrm{~cm})$.

Seed to maturity requires $80-100$ days, and transplanting to maturity requires 60-90 days, depending on the variety (Spreen et al. 1995; Brinen 2003).

Moderate amounts of fertilizer are required to achieve adequate yields in watermelon production. The plant 
responds better when nitrogen and potassium applications are split, but fertilizer application methods vary according to the production and irrigation system. For example, when full-bed mulch production with overhead irrigation is used, fertilizers are incorporated into the bed before the plastic mulch is applied, and a liquid fertilizer injection wheel is used for any later nitrogen and potassium applications. Fertilization for the second crop in a double-cropping system is achieved by using a liquid injection wheel or the microirrigation system, if applicable (Hochmuth et al. 1997; Spreen et al. 1995; Hochmuth and Elmstrom 1992; Hochmuth 1992).

In non-mulched systems with seepage irrigation, the micronutrients, phosphorus, and approximately $15 \%-20 \%$ of the nitrogen and potassium is incorporated into the bed before planting. The rest of the nitrogen and potassium is applied later as a sidedress band along the outside of the bed. When using drip irrigation, growers incorporate the micronutrients, phosphorus, and approximately $20 \%-40 \%$ of the nitrogen and potassium into the bed prior to planting and add the remaining nitrogen and potassium through drip irrigation (Hochmuth et al. 1997; Spreen 1995; Hochmuth 1992).

All types of irrigation (overhead, drip, seepage) can be used in watermelon production (Maynard 1996). Most watermelon production uses overhead sprinkler irrigation systems, except for production in South Florida, where seepage irrigation is generally used (Hochmuth et al. 1997). In north-central Florida, approximately half of the growers use drip irrigation (Brinen 2003). In general, cucurbits have slightly lower water requirements than other vegetable crops (Olson et al. 2012).

Because watermelons are very sensitive to the cold, many growers in North and Central Florida plant windbreaks during the winter to protect spring-planted watermelon seedlings from blowing sand and wind damage. The warming effect near the plant also helps achieve faster plant growth. Rye is the most common windbreak used, although sorghum and ryegrass are also effective. Sugarcane can also be used in South Florida. The windbreak is planted in strips, and on seepage-irrigated fields, windbreaks can be created in irrigation ditch areas and roadways (Brinen 2003; Hochmuth and Elmstrom 1992).

Cucurbit plants have separate male and female flowers, requiring pollen to be transferred for fruit development to occur. At least 1,000 grains of pollen must be deposited evenly on the stigma of female flowers. If pollen is not evenly deposited, the resulting fruit will not be uniform.
Honeybees are the principal pollinators, and growers usually rent hives to place in or around their fields to achieve adequate pollination. Although natural pollinators may be present, growers cannot always rely on them to provide sufficient pollination activity because they can be affected by weather conditions (Hochmuth et al. 1997; Johnson 1992).

Research on watermelon pollination in Florida has shown that female flowers require at least eight bee visitations for adequate fruit set to occur. Sufficient pollination generally requires one strong hive for every two acres, or a bee population that provides at least one bee for every 100 flowers. Hive placement is one of the many factors that may affect pollination. Hives are often placed around the perimeter of large fields for adequate distribution. Standard pollination recommendations for watermelon production in Florida are not available, and growers must work with the beekeeper to determine the optimum number of colonies and placement for each field situation (Hochmuth et al. 1997; Johnson 1992). Seedless watermelon varieties tend to require slightly higher bee populations (Maynard 1996).

Honeybee activity is greatest an hour or two after sunrise until mid-afternoon, coinciding with the time flowers remain open and most amenable to setting fruit. Most watermelon pollination occurs from 7 a.m. to 11 a.m., with the greatest percentage of fruit set resulting from insect visits between 9 a.m. and 10 a.m. Honeybees are highly susceptible to most of the insecticides used on watermelons. To avoid adversely affecting the bee colonies, any pesticide applications during the flowering period should be made at dusk or later, when bees are not active. It is recommended you have a written contract that includes detailed expectations of both the grower and the beekeeper (Hochmuth et al. 1997; Johnson 1992; Sanford and Ellis 2011).

Seedless watermelon plants do not produce enough pollen for adequate fruit set and development, so they are inter-planted with seeded pollinizer watermelon plants. The pollinizer variety is planted in the outside row and then in every third row. Or, it may be planted every third plant in a row, which may complicate harvesting. Because nearly one-third of the plants in a field will be pollinizers, the watermelons produced from them are marketed as well, and producers choose varieties that can be easily distinguished from seedless watermelons. For pollen to be available to the seedless plants at the appropriate time, direct field seeding of the pollinizer variety usually occurs at the same time that the seedless variety is planted in the greenhouse. When icebox (smaller) varieties are used as the pollinizer, direct-seeding is delayed 7-10 days because 
icebox varieties flower earlier. To assure sufficient pollen for late-blooming seedless plants, some growers make a second planting of the pollinizer variety 2-3 weeks after the first planting (Maynard 1996).

Watermelons are harvested in Florida from April 1 to July 15 , with the most active harvest period from May 1 to July 1. April and May production is primarily from southwest and west-central Florida. Growers in Central Florida begin harvesting in mid to late May, while production from north-central Florida enters the market in June (FDACS 2012; Hopkins 2003). The majority of Florida's watermelon acreage is harvested during June (Hochmuth et al. 1997). The watermelons in a field will not ripen at the same time. The first harvest produces greatest yield and quality, while later harvests cost more because fruit are smaller and lower quality, which reduces yields. Also, once watermelon harvest begins in other states, the value of Florida's crop declines significantly. Although yield is maximized by harvesting several times, many Florida growers, particularly in North Florida, only pick once or twice because of the low market prices of late-harvested watermelons (Bertelsen et al. 1994).

Watermelons are harvested once they reach an acceptable level of maturity for the intended market. Key harvest indices include yellowing of the ground spot, drying of the tendril, and dulling of the fruit surface. Fruit pulp should be sufficiently sweet, and it develops simultaneously with the deep red flesh color, also a desirable characteristic (Rushing 2004). Some specialty watermelon varieties produce yellow-fleshed fruits. If sold at local markets, watermelons are harvested when fully ripe; however, watermelons sold at distant markets must be harvested just before full ripeness to minimize damage from handling. Producers must take caution to avoid harvesting immature fruit. Immature fruit may be firm but will not develop an adequate level of sweetness (Rushing 2004). Unlike cantaloupes, watermelons will not continue to ripen after harvest.

Workers hand harvest watermelons by cutting them from the vine. One person in the field crew walks the field to indicate which melons to pick, and then cutters (one or two per row) cut and turn the melon so the ground spot is apparent. Two or three pickers per row follow the cutters, and melons are handled approximately three times before being placed in a box or truck, where one or two stackers work. Damage sustained during harvesting and handling may produce cracking and lower fruit quality and appearance. Therefore, harvest crews carefully lay the watermelons in rows and load them into padded field trucks to transport them to a collection point or a packing facility. Fruit harvested early in the morning are more likely to experience bruising and splitting than those harvested later in the day. During harvest, watermelons must be shaded from direct sunlight to minimize heating and sunburn.

At the collection point, workers unload watermelons by hand from the field trucks. Then the watermelons are sized and graded, not usually washed, and reloaded in bulk using plastic or fiberboard pallet bins and placed onto highway trucks. Round and seedless types are often packed in corrugated cartons, $2-5$ fruit each, or in pallet bins that hold approximately 1,100 pounds of fruit; many are shipped in bulk (Hochmuth et al. 1997; Sargent 1992). Fruit can also be sorted, sized, and loaded directly into bins in the field. Bulk shipments entail handling of watermelons at least five times from harvest until arrival at the retail store. Methods to reduce handling steps, such as shipping in field bins or cartons on pallets, are desirable to reduce bruising and improve overall quality. Packaged or bin-shipped watermelons typically fetch higher prices than bulk-shipped watermelons, because they are less likely to have sustained damage from handling, and handling is facilitated at receivers' docks (Hochmuth 1997; Rushing 2004; Sargent 1992).

Much of the watermelon crop harvested in Florida is shipped under ambient conditions, but some containerized watermelons shipped out of state may be held in cold rooms before shipment in refrigerated trailers. Temperatures of $50^{\circ} \mathrm{F}-60^{\circ} \mathrm{F}\left(10^{\circ} \mathrm{C}-15^{\circ} \mathrm{C}\right)$ and $<90 \%$ relative humidity are recommended to maximize postharvest quality and shelf life. However, fruit should remain refrigerated during subsequent handling; removing fruit from refrigeration will cause condensation (sweating) to form on the fruit and rapidly promote decay.

Any fruit handled above the ideal temperature is more susceptible to decay and flesh breakdown (senescence). Exposure to ethylene gas at any point during handling, storage, or transport, will also accelerate senescence and must be avoided. Ethylene is released from certain fruits and vegetables and by internal combustion engines (Hochmuth et al. 1997; Rushing 2004; Sargent 1992). Chilling injury is another cause of quality loss, occurring during storage below $50^{\circ} \mathrm{F}\left(10^{\circ} \mathrm{C}\right)$. Symptoms include fading of redness, increased juice leakage, and decay. Maintaining relative humidity below $90 \%$ will reduce incidence of stem-end rot. For best quality, watermelons should be consumed two to three weeks after harvest. 


\section{Pest Management}

The most important pest groups in Florida watermelon production are disease pathogens, particularly viral diseases, and weeds. Disease pathogens are difficult to manage, and weeds have become more difficult to manage with the loss of methyl bromide. Insect pests are generally less damaging than on other cucurbits.

Watermelon producers have access to a great deal of information regarding the production of watermelons in Florida, as well as integrated pest management programs that have been developed by researchers throughout the state and promoted through UF/IFAS Extension. Growers employ a variety of pest management techniques, particularly for disease management (Spreen et al. 1995).

\section{Alternatives to Methyl Bromide}

Researchers evaluating alternatives to methyl bromide have concluded that it will not be possible to replace it with one management tactic. A combination of tactics is needed, which varies according to the crop. A single chemical cannot replace methyl bromide; however, a combination of fumigants and non-fumigants can be used (for example, the mix of fumigants such as 1,3-dichloropropene and chloropicrin) (Noling and Gilreath 1999).

\section{Insect/Mite Management}

\section{Insect/Mite Pests}

The principal insect and mite pests on watermelons in Florida are aphids, rindworms (caterpillars feeding on the rind, including beet and fall armyworms, cabbage looper, tobacco budworm, corn earworm, saltmarsh caterpillar, and others), whiteflies, and thrips. Occasional or minor arthropod pests include seedcorn maggots, cutworms, leafminers, cucumber beetles, mole crickets, wireworms, white-fringed beetle larvae, mites, and flea beetles. Leafhoppers and fleahoppers, grasshoppers, omnivorous leafrollers, plant bugs (including lygus bugs and stink bugs), and squash bugs may occasionally be seen on watermelons but are not economically damaging (Maynard 2003; Hopkins 2003; Webb 2010; Webb 1995; Webb, Kok-Yokomi, and Voegtlin 1994).

\section{APHIDS}

Aphids attacking watermelon include melon aphid (Aphis gossypii), green peach aphid (Myzus persicae), cowpea aphid (Aphis craccivora), spirea aphid (Aphis spiraecola), Aphis middletonii, and Uroleucon pseudambrosiae, among others. Aphids constitute the principal insect pest of watermelons in Florida, primarily because of their role in virus transmission. Melon aphid, green peach aphid, and cowpea aphid feed and reproduce on watermelons and other cucurbits. The other aphids listed are important virus vectors but do not colonize watermelons. Melon aphid is the most abundant aphid colonizing watermelons in Florida. It is a major pest of cucurbits and cotton and also attacks many other plants, including eggplant, pepper, potato, citrus, okra, and a range of ornamentals and weed species (Webb, Kok-Yokomi, and Voegtlin 1994).

Aphids feed by piercing plant tissue with their needle-like mouthparts (stylets) and sucking out water and nutrients from the plant's vascular system. Evidence of damage includes thickening, crumpling, and downward curling leaves caused by feeding damage and injury from toxins in the saliva injected into plant tissue during feeding. Heavy aphid attack may kill very young plants. Aphids also deposit large amounts of honeydew on the plant surface, which encourages the growth of sooty mold. Aphid populations can increase rapidly in Florida because of a short life cycle and reproduction by live birth (Stansly 2011).

Aphids damage watermelon plants directly by feeding, as well as indirectly by transmitting viruses. The three principal viruses affecting watermelons in Florida (i.e., papaya ringspot virus type $\mathrm{W}$, watermelon mosaic virus 2 , and zucchini yellow mosaic virus) can be transmitted by aphids that colonize watermelons and by a number of aphid species that do not reproduce on watermelons. These include A. middletonii, A. spiraecola (spirea aphid, also known as green citrus aphid), and U. pseudambrosiae (Webb 2003).

These viruses are transmitted by aphids in a stylet-borne, non-persistent manner. This means that an aphid can pick up virus particles in its stylet from an infected plant and transfer them immediately to a healthy plant without the virus circulating through the aphid's body. There is no delay from when the aphid acquires the virus to when it can transmit it, but the aphid can transmit the virus for only a short period of time. An aphid determines the suitability of a plant as a food source by probing (inserting its stylet into the plant's tissue to test it). As a result, viruses can be transmitted by aphids that do not actually feed on the plant but only land on it momentarily to probe. Aphid vectors that do not feed on watermelons will move from plant to plant within a field, probing each one and spreading the virus. Aphids that do feed and reproduce on watermelons may also move from one plant to another in the field under crowded conditions, when winged individuals are produced. Virus transmission to watermelon plants can occur within 10-15 seconds (Webb 2003). 


\section{RINDWORM COMPLEX}

Any caterpillars that feed on watermelon rinds are called rindworms, including beet armyworm (Spodoptera exigua), fall armyworm (Spodoptera frugiperda), yellow-striped armyworm (Spodoptera ornithogalli), cabbage looper (Trichoplusia ni), tobacco budworm (Heliothis virescens), corn earworm (Helicoverpa zea), saltmarsh caterpillar (Estigmene acrea), and granulate cutworm (Feltia subterranea). Many rindworms also feed on the plant's foliage and stems, but the greatest damage occurs from feeding on the rind, which directly reduces the fruit's quality and marketability. Rindworms generally scar the surface of the fruit in irregular patterns, rather than boring into it. Larger caterpillars inflict greater damage, and management is generally easier when the caterpillars are smaller. Rindworms are often found on the underside or the least exposed parts of the watermelon (Webb 2003).

Beet armyworm and cabbage looper are presently the most abundant rindworms on watermelons in Florida. The cabbage looper has a wide host range. In addition to watermelons, cabbage looper also attacks cabbage and other crucifers, potato, spinach, tomato, cucumber, cotton, and soybeans. After overwintering in Florida and nearby states, it migrates north each year. Females lay their eggs on leaf surfaces of host plants, and each of the emerging larvae (caterpillars) feeds for 2-4 weeks, then spins a cocoon and pupates. Between 10 days and two weeks later, the adult moth emerges. Several generations occur each year in Florida (Webb 2003).

Beet armyworm is active throughout the year in South Florida, where many generations occur annually. A monitoring program has existed in South Florida for several years, and trap captures of beet armyworm moths are highest from late March through mid-June, corresponding to the later part of the leafy vegetable season in the region. During this time, the population rises and falls in cycles of 3-5 weeks. A smaller increase in the beet armyworm population generally occurs from mid-August through October and is likely related to the presence of late summer weeds (Nuessly and Hentz 1998). Beet armyworm moths migrate from South Florida to North Florida and other southeastern states each year. Females lay more than 600 eggs each, usually in groups of approximately 100. Eggs are laid on the underside of lower leaves. The larvae feed from 1 to 3 weeks, in groups when younger and scattered on the plant when larger. After pupating in a cocoon, the adult emerges after about one week (Webb 2003).

\section{WHITEFLIES}

Whiteflies found infesting Florida watermelons include silverleaf whitefly (Bemisia argentifolii), sweet potato whitefly (Bemisia tabaci), and greenhouse whitefly (Trialeurodes vaporariorum). The silverleaf whitefly is the most prevalent in Florida. It was previously known as strain B of the sweet potato whitefly, and it is a major pest of cucurbits and other vegetable crops in the state. The first U.S. outbreak of the silverleaf whitefly was recorded in south-central Florida in 1986, and its aggressive establishment and associated insecticide resistance have led to heavy infestations in the state's vegetable and ornamentals industries (Norman et al. 1993).

With a host range of more than 500 species of plants, the silverleaf whitefly has been observed to reproduce on at least 15 crops and 20 weed species in Florida. Whitefly populations commonly peak on the state's crops at harvest time, as the whitefly migrates from crop to crop throughout the year. In South Florida, populations build on fall vegetables and move directly to overlapping spring crops. In south-central Florida, the whitefly uses cabbage and other winter crops to survive until the spring. During the summer fallow period, whitefly populations are low because whiteflies are limited to weeds, such as water primrose, hairy indigo, and spurge. Weeds are poor hosts to the whitefly and usually harbor many natural enemies that further reduce populations (Norman et al.1993; Stansly 1995).

Whiteflies damage watermelon plants by removing plant sap, depleting the plant of needed nutrients. On some hosts, whiteflies cause severe damage by transmitting plant viruses. On watermelons, whiteflies have been reported to transmit squash leaf curl and lettuce infectious yellows, but these viruses do not presently occur in Florida. In Florida, the principal damage to watermelons inflicted by whiteflies is caused by feeding, which greatly reduces the plants' vigor under heavy infestations (Webb 2003).

Adult females produce an average of 160 eggs each, depositing them on the lower surface of host plant leaves. The first nymphal (immature) stage, the crawler stage, attaches itself to the leaf near the empty egg case. The whitefly passes through three more sedentary nymphal stages, appearing like transparent scales, before molting to the adult stage. Whiteflies feed by sucking the plant's sap through their needle-like piercing-sucking mouthparts. Like aphids, they extract large amounts of the plant's sap (phloem) and excrete the excess liquid as honeydew. Sooty mold can then 
grow on the honeydew (Webb 2003; Norman et al.1993; Johnson, Short, and Castner 2005).

Similar to aphids, whiteflies are found mainly on the lower leaf surface, and only the first nymphal stage and the adults can move, so control using insecticides is limited if complete coverage is not achieved. Alternating insecticides is important to minimize the development of resistance. Managing whiteflies requires a combination of tactics, with an emphasis on cultural control.

\section{THRIPS}

Thrips found on Florida watermelon include tobacco thrips (Frankliniella fusca) and melon thrips (Thrips palmi). Tobacco thrips is a problem on watermelons in Central and North Florida but is rarely found in South Florida. They damage watermelons primarily in the seedling stage, with little or no damage observed once plants begin to grow rapidly. Feeding mainly occurs in the terminal buds, producing scarred leaves with silvery or clear areas that look as if they were damaged by blowing sand. Crinkling of tissue and the appearance of chlorotic areas can also result. Heavy infestations can stunt watermelon plants (Webb 1995; Webb 2003).

Melon thrips is an important insect pest on watermelons in South Florida and is only found in that part of the state, where it is a relatively new pest. It was first reported in early 1991 in the Homestead area (Miami-Dade County). It has caused large economic losses in several vegetable crops, particularly snap bean, pepper, eggplant, cucumber, winter melon, and squash. In addition to those crops and watermelons, melon thrips also feeds on cantaloupe, potato, tobacco, soybean, broad bean, spinach, and amaranth. Both adult and immature thrips feed in groups on leaves, stems, flowers, and fruits, removing sap with their sucking mouthparts. Feeding by melon thrips on watermelons results in a bronzed appearance on leaves. However, greatest damage occurs from feeding at the tips of vines, which restricts canopy development (Webb 2003; Tsai et al. 1995; Sakimura, Nakahara, and Denmark 1986; South 1991).

Melon thrips is present throughout the growing season in South Florida but is most abundant between December and April. The pest completes its life cycle in approximately 20 days at $86^{\circ} \mathrm{F}\left(30^{\circ} \mathrm{C}\right)$ and approximately 80 days at $59^{\circ} \mathrm{F}$ $\left(15^{\circ} \mathrm{C}\right)$. Each female thrips produces an average of 50 eggs, which are deposited in slits the female makes in the leaf tissue. Larvae usually feed on older leaves, concentrating along the leaf midrib and veins. After passing through two larval instars in $4-5$ days (at $79^{\circ} \mathrm{F}-90^{\circ} \mathrm{F}$ or $26^{\circ} \mathrm{C}-32^{\circ} \mathrm{C}$ ), the larva drops to the ground, where it passes the prepupal and pupal stages in a soil chamber it has constructed. After 3-4 days (at $79^{\circ} \mathrm{F}-90^{\circ} \mathrm{F}$ ), the adult emerges and seeks out new host plant leaves to feed on (Webb 2003).

The relationship between early damage from thrips and watermelon yield has not been determined. Melon thrips is resistant to many insecticides. In addition, the use of broadspectrum insecticides may increase populations of melon thrips by killing off natural enemies that may contribute to thrips management in the field. Use of insecticides also requires thorough spray coverage and is not effective against the egg and pupal stages, which are protected (Stansly 2011; Webb 2003; South 1991).

\section{SEEDCORN MAGGOT}

Seedcorn maggot (Delia platura) often reduces plant stand in Central Florida by attacking young emerging seedlings. Seedcorn maggot adults are small flies that become active early in the spring, laying their eggs where organic matter is high, such as in manure or where cover crops have been plowed under. They also lay eggs at the base of transplants. Upon hatching, the maggots enter the seed or the stem of the developing seedling. Injury from seedcorn maggot feeding results in wilting and plant death. Maggots feed on organic matter for 2-3 weeks, passing through three larval stages (instars) during that time. As the weather warms, the adult flies seek wooded areas, where the insect oversummers in the pupal stage. The flies are most active during cool, wet springs. Transplanting or seeding into soils with temperatures of at least $72^{\circ} \mathrm{F}\left(21.3^{\circ} \mathrm{C}\right)$ at a depth of 4 inches $(10 \mathrm{~cm})$ will reduce likelihood of damage from seedcorn maggot (Webb 2003).

\section{CUTWORMS}

Cutworms, including granulate cutworm (Feltia subterranea) and others, are stout caterpillars with a dull, greasy appearance. Several cutworms, particularly granulate cutworm, can attack watermelons in Florida (Webb 2010). Cutworms are exclusively a problem for young watermelon seedlings. They are active at night, but retreat to the soil or under surface litter during the day. They often cut the main stem of the seedling at the base and can greatly reduce stands of newly emerged watermelon plants. Cutworms can also climb the plant stem to feed on foliage. Being more prevalent in spring and fall, they overwinter in the larval stage, often in grasslands. Baits applied for cutworm control should be laid out in the afternoon or early evening for maximum effectiveness (Webb 2003). 


\section{LEAFMINERS}

Leafminers (Liriomyza sativae and Liriomyza trifolii) are occasionally a major pest of watermelons in South Florida. The adult fly punctures the upper leaf surface while feeding, and the female inserts eggs into the puncture holes. When each larva (maggot) emerges, it feeds between the upper and lower leaf surfaces, creating a tunnel or "mine" that winds across the leaf and becomes larger as the maggot grows. When larval development is complete, after about two weeks, the maggot cuts through the leaf surface and emerges from its mine, dropping to the soil to pupate. Where watermelons are grown on plastic mulched beds, leafminer pupae can be seen on the surface of the plastic. Leafminer populations can increase rapidly in Florida, where the life cycle can be as short as 18-21 days (Webb 2003).

Infestations are often more severe late in the season. Under heavy infestations, leaves may be nearly covered with mines, and defoliation late in the season can result in sunscald damage on the fruit. Adequately managing leafminer populations in watermelon seedlings is particularly important because the mines can serve as entry points for the fungus that causes gummy stem blight, an important watermelon disease in Florida (Hochmuth and Elmstrom 1992; Webb 2003).

\section{CUCUMBER BEETLES}

In Florida, cucumber beetles include banded cucumber beetle (Diabrotica balteata), striped cucumber beetle (Acalymma vittata), and spotted cucumber beetle ( $D$. undecimpunctata howardi). These beetles occasionally feed on watermelons in Florida to the degree that control measures become necessary. Banded cucumber beetle is more prevalent in South Florida, while spotted cucumber beetle is most common in North Florida. Striped cucumber beetle is seen only occasionally, primarily in western and northern Florida (Watson and Tissot 1942).

Cucumber beetles prefer to feed on cucurbit plants such as squash, cucumber, and cantaloupe in addition to watermelon, but they can also feed on a wide range of crops, including corn, beet, pea, sweet potato, okra, lettuce, onion, cabbage, potato, and tomato. Spotted cucumber beetle, with larvae known as southern corn rootworm, is the most general feeder of the three, having been recorded on more than 200 species of crops, grasses, and weeds. Feeding damage from adult cucumber beetles results in ragged holes in the leaves, and the beetles may also feed on stems. The larvae are found in the soil and feed on the roots of the vines and the underside of the watermelon fruits laying on the soil.
These beetles have the greatest effect on watermelon yield when plants are attacked at the seedling stage. Older plants can withstand higher amounts of feeding damage. When cucumber beetles are found on $10 \%$ of seedlings, control measures should be instituted (Watson and Tissot 1942; Capinera 2011; White 1964).

Cucumber beetles have many generations each year. The life cycle of the banded cucumber beetle may be as short as 45 days under optimal conditions. During a two- to eightweek period, each female banded cucumber beetle deposits 2-15 clusters of up to 100 eggs in soil cracks, with each female depositing up to 850 eggs. Striped cucumber beetle females lay approximately 100 eggs each, at the base of host plants. The larvae hatch after 5-9 days. Banded cucumber beetles pass through three instars in 11-17 days (somewhat longer for striped and spotted cucumber beetles), during which time the larvae feed on roots and tunnel through stems of host plants, and pupation occurs in the soil. Adult banded cucumber beetles emerge after 4-6 days. Approximately 16 days after adults emerge, females begin to lay eggs. Adults live for 17-44 days, with average longevity of 26 days (Watson and Tissot 1942; Capinera 2011).

\section{MOLE CRICKETS}

Mole crickets (Scapteriscus spp.) occasionally present a problem to watermelon producers in Florida. They damage young seedlings by feeding on and tunneling in and around the roots often girdling the stems at their base. Their presence can be confirmed easily by the tunnels they make just below the soil surface. Mole crickets are active at night, particularly on warm nights when soil is moist, and they are rarely seen during the day (Schuster and Price 1992).

Mole crickets overwinter as adults or older nymphs, often a foot or more below the soil surface. Adults deposit their eggs in chambers they make in the soil, usually 4-12 inches below the surface. Nymphs hatch after three weeks, and they feed for many weeks before reaching the adult stage. Although mole crickets may attack many vegetable crops, they prefer pasture and grass, where large populations are generally found in Florida. Mole crickets are more likely to be a problem if pastureland is rotated to watermelons, a common practice in North Florida (Schuster and Price 1992; Frank, Fasulo, and Short 1998).

\section{WIREWORMS}

Wireworms (Conoderus spp.), the larvae of click beetles, are among the most destructive of soil insect pests. Conoderus spp. wireworms, including C. rudis, C. amplicollis (Gulf wireworm), C. falli (southern potato wireworm), and $C$. 
verpertinus (tobacco wireworm), are the most common on vegetable crops in Florida. Wireworms cause the greatest damage to germinating seeds, and transplants are generally less susceptible. In addition to attacking seeds before or at germination, wireworms can bore into the tap root and tunnel up the stem or feed on smaller roots of seedlings. They can cause sudden stand reductions by quickly attacking young seedlings, causing wilting, stunting, and death. Click beetles lay their eggs in the soil near plant roots, and on hatching, the wireworms feed on the nearby roots. Wireworms may spend up to several years in the soil in the larval stage and may be present at a soil depth of 1-5 feet (0.3-1.5 meters) (Brinen 2003; Stansly 2011).

Similar to mole crickets, wireworms are more numerous in pasture and grass, so watermelons planted to land previously used for pasture is likely to experience greater wireworm problems. Chemical controls for wireworms must be applied before or at planting.

\section{WHITE-FRINGED BEETLE}

White-fringed beetle (Graphognathus spp.) is an occasional pest on watermelons and other crops in North Florida. It prefers cotton, peanut, okra, soybean, cowpea, sweet potato, beans, and peas, but most vegetable and field crops are attacked by this pest. It has a host range of more than 385 species. Larvae (grubs) feed on roots, tubers, underground stems, and dead plant matter, and can inflict serious damage to the taproot by boring into it. In addition to directly killing the seedling, grub damage to roots leaves the plant susceptible to root infections. White-fringed beetle grubs may damage plants in only a few scattered areas within a field or may affect nearly all plants within a field. Adults feed on leaves of host plants, cutting out notches along the leaf margins. They lay eggs in the soil at the plant base, and the grub stage can live up to two years in the soil. Currently no insecticides are effective against the grub, although several insecticides are available for adult white-fringed beetles. The presence of white-fringed beetle grubs is best determined by the crop history of the land. Watermelons should not be planted to land infested with white-fringed beetle grubs (Dixon 1988).

\section{SPIDER MITES}

Spider mites, the most common type of mite affecting crop plants, are occasionally pests on watermelons in Florida. They feed on the underside of leaves, primarily along the midribs and lateral veins. After piercing the leaf surface, they suck up the plant's sap. Mite feeding causes watermelon plants to turn pale, then yellow, and eventually brown, and the plant appears dusty. Under severe infestations, foliage dries up and dies. When many mites are present, silken webs and white flakes of molted skin can be observed on the leaf surface. Mites move from one plant to another by parachuting through the air on their webs, using the wind. When their path is interrupted by an obstacle, they crawl down and seek out host plants. Infestations begin along edges of fields and close to high objects such as fences or trees.

Before using chemical controls, you should determine the age structure of the insect population under Florida's warm conditions. When many nymphs are present, the population is probably increasing, whereas if many adults are present, particularly males, it is probably declining. In addition, if a miticide is used, a second application is necessary in Florida 5-7 days following the first. The second application kills the mites that escaped the first application because they were in the egg stage. Timing is critical to prevent those mites from maturing and laying eggs (Stansly 2011).

\section{Chemical Control}

In 2010, Florida growers applied insecticides/miticides totaling 38,500 pounds of active ingredient to $81 \%$ of the state's watermelon acreage. During the years usage data was collected, $38 \%-81 \%$ of watermelon acreage was treated with insecticides each year, with total annual usage ranging from 12,700 to 47,400 pounds of active ingredient. Older insecticides labeled for use on Florida watermelon include Bacillus sp., esfenvalerate, permethrin, carbaryl, abamectin, bifenthrin, diazinon, dimethoate, imidacloprid, malathion, methomyl, oxamyl, spinosad, azadirachtin, cyromazine, cryolite, fenpropathrin, kaolin, oils, oxydemeton-methyl, pymetrozine, pyrethrins + rotenone or silicon dioxide, soaps, and sulfur. Newer insecticides registered include acetamiprid, bifenazate, indoxacarb, beta-cyfluthrin, clothianidin, flonicamid, flubendiamide, iron phosphate, pheromones, chlorantraniliprole, buprofezin, deltamethrin, potassium salts of fatty acids, Myrothecium verrucaria, thiamethoxam, lambda-cyhalothrin, pyriproxyfen, piperonyl butoxide, (s)-methoprene, avermectin b1, zeta-cypermethrin, methoxyfenozide, Paecilomyces sp., Chromobacterium subtsugae, extract of Chenopodium ambrosioides, spiromesifen, fenpyroximate, sodium tetraborohydrate decahydrate, spinetoram, cyfluthrin, novaluron, dinotefuran, 1,3-dichloropropene, chloropicrin, and etoxazole (USDA/NASS 2011b; CDMS 2013; USDA/ NASS 2011c). 


\section{ESFENVALERATE}

Esfenvalerate is a broad-spectrum, synthetic pyrethroid insecticide used on watermelons in Florida. During most years, it is primarily used to manage cutworms, corn earworm, and cabbage looper. It also helps in managing cucumber beetle adults, leafhoppers, grasshoppers, plant bugs (including lygus bugs and stink bugs), squash bugs, and squash vine borers (Webb 2010). Esfenvalerate may be applied up to 3 days before harvest (pre-harvest interval = 3 days), and the restricted-entry interval (REI) under the Worker Protection Standard (WPS) is 12 hours. A maximum of 0.25 pounds of active ingredient may be applied per acre during each season (CDMS 2013).

In 2010, Florida growers applied an average of 0.03 pounds of active ingredient per application to $9 \%$ of watermelon acreage, an average of 2.6 times. Total usage was 200 pounds of active ingredient. During the years usage data was collected, Florida watermelon growers applied esfenvalerate at an average rate ranging from 0.03 to 0.07 pounds of active ingredient per acre at each application to $4 \%-18 \%$ of watermelon acreage. Growers have made an average number of applications ranging from 1.8 to 4.7 each year, totaling $100-1,300$ pounds of active ingredient annually (USDA/NASS 2011c).

\section{Cultural Control}

Planting early is one of the most effective cultural controls for most insect pests of watermelons. Early production is an important goal of Florida watermelon growers because of market considerations, so this practice is common. Early planting even for the fall crop is useful, because aphid populations tend to decline in mid-summer and do not build again until later in the season (Webb 2010).

To reduce aphid populations and the resulting spread of aphid-vectored viruses, watermelons planted during the summer for a fall harvest should be planted far from fields in cucurbit production the previous spring. In addition, weeds in and around the field that may harbor aphids should be eliminated. Using mineral oil (stylet oil) can disrupt the transmission of non-persistent viruses by interfering with the transfer of virus particles to and from aphid mouthparts. Oil sprays on watermelons in Florida applied at four- to five-day intervals beginning early in the season have been shown to delay primary infection by slowing the start of viral epidemics in the crop and reducing viral spread. Stylet oil is most effective when virus incidence is low (less than 20\%). Low virus incidence occurs under conditions of limited inoculum, so stylet oil is most effective for spring-planted watermelons in Florida.
Economic analysis has shown that the cost of 12-15 applications of stylet oil during the season is offset if the oil increases yield by $5 \%-7 \%$ (Hochmuth and Elmstrom 1992; Webb and Linda 1993).

Producers have also tried using white mulch or reflective mulch (usually black plastic painted with aluminum) to repel aphids by preventing them from landing on the watermelon plants. However, reflective mulches only had limited effectiveness, particularly as the season progresses and the plant foliage covers the mulch. In addition, white or reflective mulches delay warming of the soil in the early spring, a key concern for Florida watermelon producers (Webb 2010).

Aphids, whiteflies, and thrips populations are all affected by surrounding crops and vegetation, and properly managing weeds and crop residues is an important tactic. Destroying crop residues in and around fields can also prevent movement of leafminers, which particularly damage late-planted watermelon fields. In addition to destroying crop residues and avoiding planting near infested crops, cultural controls for whiteflies include early planting, rotating with non-susceptible crops, using reflective mulches, and using physical barriers such as floating row covers (Webb 2003; Norman et al. 1993).

Florida vegetable growers commonly turn the soil several times to expose wireworms to sunlight. Deep plowing at least 30 days before planting can reduce all populations of soil insects by exposing the insects to bird predation and harsh environmental conditions. Deep plowing also denies soil insects the grass and weed sources that serve as alternate food. White-fringed beetle grubs can best be managed by planting infested land to grass or grains for extended periods (Webb 2003).

\section{Biological Control}

Aphid predators (larvae of ladybird beetles, syrphid flies, and lacewings) and parasitic wasps have been observed to reduce aphid populations in north-central Florida later in the season. However, aphid natural enemies are not present in great enough numbers during the early part of the season to effectively manage aphid populations as a control measure by themselves (Webb 1996).

A number of predators, pathogens, and parasitic insects naturally attack rindworm complex caterpillars in Florida. For example, cabbage loopers have been found to be infected with nuclear polyhedrosis virus and attacked by a number of parasitic insects, including wasps and tachinid 
flies. A protozoan (Microsporidium sp.) has been observed to attack granulate cutworm, and fungal pathogens and nuclear polyhedrosis virus both attack beet armyworm (Webb 2003).

Leafminer populations in watermelons are kept down by a number of parasites. However, natural enemies are susceptible to toxic pesticides used on the crop (Webb 2003). In the absence of broad-spectrum insecticides, several types of organisms naturally manage whitefly populations. Predators include green lacewing larvae and ladybird beetles. Whiteflies are also killed by parasitic wasps, such as Encarsia spp. and Eretmocerus spp., as well as by disease-causing fungi, such as Beauveria, Paecilomyces and Verticillium. Insect pathogens for managing silverleaf whitefly are currently being studied under field conditions, but commercial formulations are not yet available (Norman et al. 1993).

Several natural control agents of melon thrips have been evaluated for their potential to manage the pest in Florida, including the eulophid wasp (Ceranisus menes) and the predatory mite (Neoseiulus cucumeris). But research has not been completed on the effectiveness of these and other natural enemies in managing thrips on watermelon (Castineiras, Baranowski, and Glenn 1996; Castineiras, Baranowski, and Glenn 1997). Several fungal pathogens are also known to infect melon thrips, including Neozygites parvispora, Verticillium lecanii, Hirsutella sp., Beauveria bassiana, and Paecilomyces fumosoroseus. Preliminary studies of Beauveria bassiana and Paecilomyces fumosoroseus in Florida show potential for thrips management, but more research is needed to determine the effect of these fungi on thrips populations under field conditions (Castineiras et al. 1996).

Research efforts are under way for several biological controls of mole crickets because of the severe damage to Florida turfgrass, pasture grass, and vegetables. Presently, the most effective biological control agent for mole crickets is a steinernematid nematode. The nematode was first brought to Florida from Uruguay in 1985 and identified as Steinernema scapterisci (Nguyen and Smart 1990). This parasitic nematode has shown promise for managing mole crickets in pasture and turf in Florida, and is available commercially for mole cricket control in turf. It has been shown to be highly effective against tawny mole crickets and less effective against short-winged mole crickets. It is most effective as a biocontrol agent in areas where mole cricket populations are highest, such as in pastures. The nematode can also be applied as a biopesticide in areas where mole cricket populations are lower, and it shows residual activity. The nematode disperses well when applied and has been recovered from infected mole crickets years after its application.

One reason it is effective is that mole crickets in North Florida have only one generation each year, while, under appropriate conditions, the nematode could produce a new generation every 10 days during eight months of the year. Populations of the nematode have become established in small areas of several Florida counties. If it becomes established in pastures surrounding vegetable crop production areas, it is expected to keep mole cricket populations below damaging levels (Frank, Fasulo, and Short 1998; Frank 1994).

\section{Disease Management Disease Pathogens}

Diseases, particularly those produced by viruses, are the most serious pest problem on watermelons in Florida. The state's warm, moist climate, as well as the overlapping progression of watermelon plantings during the season from South Florida to the northernmost regions, creates conditions ideal for disease development. The incidence of the various diseases affecting watermelons in Florida varies by region, given the climatic differences in the state. Intensity of management efforts also varies by region. South Florida growers generally experience greater disease pressure, but earlier harvests in that region provide higher market prices, giving them the resources to aggressively manage diseases (Roberts and Kucharek 2005).

Three potyviruses that infect watermelon (papaya ringspot virus, watermelon mosaic virus 2 , and zucchini yellow mosaic virus) occur annually in Florida. The viruses are spread by aphid vectors from infected watermelon plants or weeds to healthy watermelon plants. Because the aphids acquire and spread the viruses in a non-persistent manner, insecticidal control is not effective. Generally, growers have observed spray efforts to be futile and instead concentrate their management efforts on other tactics. Cucurbit viruses are among the most difficult of Florida's pests to manage. Florida watermelon crop loss as a result of viruses varies each year and by place. For example, little damage occurred from viruses in 1998 as a result of their late arrival that year, but in any year, fields with losses of $50 \%-100 \%$ are common (Roberts and Kucharek 2005).

The most important fungal diseases are gummy stem blight (caused by Didymella bryoniae/Phoma cucurbitacearum) and downy mildew (caused by Pseudoperonospora cubensis). Some consider gummy stem blight to be the most troublesome disease on watermelons in Florida. Other 
occasional or minor diseases include phytophthora blight (caused by Phytophthora capsici), bacterial fruit blotch (caused by Acidovorax avenae subsp. citrulli), alternaria leafspot (caused by Alternaria cucumerina), seedling blight (caused by Pythium spp., Rhizoctonia solani, and Fusarium spp.), fusarium wilt (caused by Fusarium oxysporum f.sp. niveum), angular leafspot (caused by Pseudomonas syringae), anthracnose (caused by Colletotrichum orbiculare), rind necrosis (usually caused by Erwinia spp.), and powdery mildew (caused by Erysiphe cichoracearum). Blossom end rot, a physiological disorder related to calcium deficiency and water stress, is also an occasional problem. Finally, Cercospora leafspot (caused by Cercospora citrullina) and southern blight (also called southern stem rot or white mold and caused by Sclerotium rolfsii) are only rarely seen on watermelons in Florida (Hochmuth et al. 1997; Maynard 2003; Roberts and Kucharek 2005).

\section{PAPAYA RINGSPOT VIRUS TYPE W}

Formerly referred to as watermelon mosaic virus 1, papaya ringspot virus type $\mathrm{W}(\mathrm{PRSV}-\mathrm{W})$ is a greater problem in South Florida, where it can severely damage the crop. Epidemics of papaya ringspot virus have been linked to weeds as the primary source of inoculum (Roberts and Kucharek 2005). Papaya ringspot virus has been shown to overwinter in wild cucurbits such as wild balsam apple and creeping cucumber, and it is spread from these to spring-planted watermelons in South Florida. During most years, the virus reaches Central and North Florida in early summer (Webb and Linda 1993).

\section{WATERMELON MOSAIC VIRUS 2}

Watermelon mosaic virus 2 (WMV-2) is another potyvirus that causes regular problems for watermelon production, particularly in Central and North Florida during spring production. Incidence of watermelon mosaic virus 2 in Central Florida rarely exceeded 5\% during the 1960s and 1970s. However, in the late 1980s, the virus caused severe losses to the spring watermelon crop in Central and North Florida, with incidence in fields of up to $100 \%$. Infection early in the season results in yield loss and reduced fruit quality because of blemishes, particularly rings and spots on the watermelon rind. However, if the virus does not enter a field until the time of fruit set, little to no yield difference is likely (Webb, Kok-Yokomi, and Voegtlin 1994; Webb and Linda 1993).

The virus is transmitted in a non-persistent manner by numerous species of aphids, including Myzus persicae, Aphis spiraecola, Aphis middletonii, Aphis illinoisensis, and Uroleucon pseudambrosiae (Webb and Kok-Yokomi 1993;
Adlerz 1978; Adlerz 1987). During the summer and fall, watermelon mosaic virus 2 builds up in many cucurbit and leguminous summer annuals, including hairy indigo (Indigofera hirsuta), showy crotalaria (Crotalaria spectabilis), alyceclover (Alysicarpus vaginalis), and Florida beggarweed (Desmodium tortuosum). These hosts serve as sources of inoculum for the fall watermelon crop, and their presence is probably the reason that fewer aphids are necessary to initiate virus epidemics on the fall crop than on the spring crop. The source of inoculum for the spring watermelon crop has not yet been identified. The major factor in the appearance of spring epidemics of WMV-2 in Florida is secondary spread of the virus because primary infections in watermelon fields are limited (Webb and Linda 1993).

\section{ZUCCHINI YELLOW MOSAIC VIRUS}

Zucchini yellow mosaic virus (ZYMV), the third potyvirus affecting watermelon production in the state, was first observed in Florida in 1981 and identified in 1984. At that time, researchers demonstrated that it caused mosaic symptoms in watermelons and other cucurbits and could be transmitted by the aphids Myzus persicae and Aphis spiraecola (Purcifull et al. 1984). The incidence of zucchini yellow mosaic virus is generally lower than the other two potyviruses that affect watermelons. In Central Florida, zucchini yellow mosaic virus is most common in late spring and fall. The virus causes more severe symptoms than the watermelon mosaic virus 2 , with resulting discoloration and distortion of fruits (Webb and Linda 1993).

\section{GUMMY STEM BLIGHT}

Gummy stem blight (caused by Didymella bryoniae/Phoma cucurbitacearum) is one of the most important diseases of watermelons in Florida. It can affect most aboveground parts of the watermelon plant. Symptoms may be difficult to distinguish from other foliar diseases and include brown to black leaf spots, stem cankers, or fruit spots. Lesions eventually develop black spots, which are the fruiting bodies of the fungus (pycnidia). A brown, gummy material may be produced on the surface of lesions. On watermelon, the disease is referred to as black rot. It produces water-soaked spots on the fruit, which leak gummy material (Roberts and Kucharek 2005; Maynard and Hopkins 1999).

The fungus that causes gummy stem blight can be found on crop debris, in the air (as airborne spores), in and on contaminated seed, and on volunteer and wild cucurbits. The principal source of inoculum for the disease is infected debris from other cucurbit plants. Airborne spores (ascospores) are important in the field-to-field spread of the fungus, and they have been detected throughout the year 
in Florida, with a peak during June and July. The pycnidiospores, produced in the pycnidia, spread the pathogen from plant to plant within a field, principally through splashing rain. At least one hour of free moisture on leaves is required for infection to occur, and lesions continue to expand only when leaves are wet. Disease development is most rapid when frequent rains occur (Roberts and Kucharek; Maynard and Hopkins 1999).

\section{DOWNY MILDEW}

Downy mildew (caused by Pseudoperonospora cubensis) is another key fungal disease of watermelons in Florida. It occurs principally in South Florida, and its likelihood of occurrence in the state decreases with distance to the north. It occurs every year in South Florida, while in North Florida its presence is sporadic. Ideal conditions for the development of downy mildew include nighttime temperatures of $55^{\circ} \mathrm{F}-75^{\circ} \mathrm{F}\left(12.8^{\circ} \mathrm{C}-23.9^{\circ} \mathrm{C}\right)$ and relative humidity above $90 \%$. In South Florida, watermelons planted in the fall and spring may be infected with downy mildew as early as the appearance of the first true leaves (Roberts and Kucharek 2005).

Downy mildew attacks foliage, producing lesions on the leaves that can cause the plants to wilt. The lesions can kill them if they are severely infected early in their development. Initial symptoms include small yellow spots, which may be angular, grow to one-half inch $(1.3 \mathrm{~cm})$ or more in diameter, and turn brownish in color. Leaves of watermelon plants may curl upward dramatically as a result of the lesions. The disease can reduce yield and lower fruit quality. The principal source of inoculum in South Florida is probably volunteer watermelon plants. Spores are produced mainly on the underside of the leaves or in the lesions, and are dispersed by wind to other plants, primarily from late morning to midday. In the presence of moisture, spores that land on a leaf germinate and enter the leaf tissue. New lesions are produced in 4-7 days, and downy mildew spreads rapidly if not controlled (Roberts and Kucharek 2005).

\section{PHYTOPHTHORA BLIGHT}

Phytophthora blight (caused by Phytophthora capsici) occurs sporadically in Florida, but the disease can spread rapidly if the weather is favorable to the fungus, causing serious losses. In 1998, the disease was widespread and severe on several vegetable crops in Florida. In the southwest region of the state (Lee, Collier, and Hendry Counties), 25\% of watermelon plants in some surveyed fields were found to have the disease, and disease incidence on watermelons in Manatee County was 36\%. Previously, phytophthora blight had affected only the fruit of watermelons, but during the 1998 outbreak, many watermelon plants were affected and died in Manatee County, regardless of plant age. In untreated test plots at the UF/IFAS Southwest Research and Education Center in Immokalee, 100\% plant mortality occurred on watermelon plants of the variety 'Regency' (Gevens et al. 2011; Roberts and McGovern 1998).

The fungus causes a seed rot and seedling blight (dampingoff). Seedlings may become discolored at the base and fall over. Under moist conditions, the white fungal growth can be observed. In mature watermelon plants, foliar symptoms appear as water-soaked (greasy-looking) blotches, which later dry out and turn brown. Some runners may experience dieback. Although such symptoms may appear under highly favorable conditions, as occurred in 1998, phytophthora blight primarily produces a fruit rot on watermelons. Irregular brown lesions on the fruit expand rapidly to round or oval lesions that may contain concentric rings. The fungal body (mycelium) appears as a cottony, white or gray growth in the center of the rotted tissue, surrounded by brown, water-soaked areas. The disease causes the entire fruit to eventually decay (Gevens et al. 2011; Roberts and McGovern 1998).

Phytophthora capsici spreads from plant to plant by wind or water in the form of swimming spores (zoospores), which require sufficient surface moisture to infect host tissue. Disease development is most rapid during warm, wet weather $\left(75^{\circ} \mathrm{F}-90^{\circ} \mathrm{F}\right.$ or $\left.24^{\circ} \mathrm{C}-32^{\circ} \mathrm{C}\right)$ and in low, waterlogged areas of the field or during excessive rainfall. During the 1998 epidemic, disease development continued rapidly even after rainfall ended, suggesting that moisture on leaf surfaces from dew and fog is sufficient for spread of spores. When ideal conditions are present, symptoms of phytophthora blight may be observed in 3-4 days after infection. The fungus can survive on seed and in the soil on host plant debris in the form of thick-walled spores (oospore). These survival structures can survive in the soil for at least two years and serve as the source of inoculum for later crops (Maynard and Hopkins 1999; Gevens et al. 2011; Roberts and McGovern 1998).

\section{BACTERIAL FRUIT BLOTCH}

Bacterial fruit blotch (caused by Acidovorax avenae subsp. citrulli) occurs sporadically, affecting only a limited number of fields, but it can cause severe losses where it occurs. Also called greasy fruit spot or watermelon fruit blotch, this bacterial disease is a relatively new problem in Florida watermelon production. In 1989, the first year it was observed in the state, losses of $50 \%-90 \%$ of marketable fruit occurred in some fields. When an outbreak occurs early in 
the season, no marketable fruit may be harvested (Roberts and Kucharek; Somodi et al. 1991; Hopkins, Cucuzza, and Watterson 1996; Latin and Hopkins 1995).

The pathogen produces both a leafspot and a fruit spot, and symptoms can occur on seedlings, leaves, and fruit. When it attacks seedlings, water-soaked lesions form, and the seedling can collapse and die. Found principally along the major veins, lesions on the leaves are light to reddish brown and can occur throughout the season. Although they are generally inconspicuous and do not usually contribute to defoliation, leaf lesions serve as reservoirs of the bacteria that later infect the fruit. On the watermelon fruit, lesions start as very small, water-soaked areas that usually do not appear until close to harvest. Later, they enlarge, and within two weeks, they may cover the entire upper surface of the fruit. Cracks may later appear on the rind, which may show internal discoloration, and the whole fruit may rot within, as secondary pathogens enter the open lesions (Roberts and Kucharek 2005; Somodi et al. 1991; Hopkins, Cucuzza, and Watterson 1996; Hopkins 1991; Frankle, Hopkins, and Stall 1993).

Bacterial fruit blotch is transmitted by seed, the principal source of epidemics in Florida. In addition to infected seed, the disease can enter watermelon fields through infected transplants, infected volunteer watermelons, and possibly from infected wild cucurbit plants. For example, wild citron, a common weed throughout the southeastern United States, is highly susceptible to the disease. Conditions in transplant production facilities (such as the warm, humid environment and the use of overhead irrigation that can splash bacteria to nearby seedlings) can contribute to a high level of secondary spread. In the field, the pathogen spreads among plants and from leaf lesions to watermelon fruit. Seeds from infected fruit that rot in the field can fall to the soil, producing infected volunteer plants that are a source of local inoculum during the next season (Latin and Hopkins 1995; Hopkins 1991).

\section{ALTERNARIA LEAF SPOT}

Alternaria leaf spot (caused by Alternaria cucumerina) is a minor disease on Florida watermelons. Symptoms begin on the upper surface of older leaves as very small yellow or tan spots that may be surrounded by light green or yellow halos or by a water-soaked area. The spots later grow up to $3 / 4$ of an inch $(2 \mathrm{~cm})$ in diameter and turn brown in color. Similar in appearance to gummy stem blight, the lesions are the source of spores spread primarily by the wind. Under severe infestations, the disease produces leaf curling, defoliation (which leaves the fruit susceptible to sunscald), and premature ripening. Lower yields, lower fruit sugar, and fruit deformity may occur (Roberts and Kucharek 2005).

The fungus can survive on or in crop debris, with debris on the surface more likely to spread spores because of exposure to the wind. Volunteer cucurbit plants and weeds, such as balsam apple, are also sources of inoculum. When watermelons are planted successively for multiple harvest dates, older infested plants located upwind can also contribute to disease spread. Although wind is the main vehicle for spore dispersal, movement by rain splash and mechanical means can also occur. As in other fungal diseases, spores require moisture to germinate and enter the leaf tissue, while spore release from the plant is best achieved under dry conditions. The optimum temperature for infection is $68^{\circ} \mathrm{F}\left(20^{\circ} \mathrm{C}\right)$, and in $3-12$ days from spore penetration, the next group of spores is released.

\section{SEEDLING BLIGHT}

Seedling blight (caused by Pythium spp., Rhizoctonia solani, and Fusarium spp.) can kill seedlings before or after they emerge. Rot symptoms, either wet or dry, are observed in the presence of this disease. The lesions resulting from seedling blight caused by Rhizoctonia solani are reddishbrown to orange and appear sunken. Pythium spp. cause shoots or roots to appear gray and water soaked. The incidence of seedling blight is higher when watermelons are planted in cool soils because seedlings that emerge slowly are more susceptible to pathogenic fungi (Roberts and Kucharek 2005).

\section{FUSARIUM WILT}

The fungus responsible for fusarium wilt of watermelons is soilborne and is widespread in many fields. Fusarium wilt (caused by Fusarium oxysporum f.sp. niveum) occurs commonly in Florida when resistant varieties are not used. However, the disease often occurs even when resistant varieties are used. Resistance to fusarium wilt is not complete, meaning that some plants will be susceptible even with the use of resistant varieties. In addition, resistance to only two of the three races of the fungus has been incorporated into resistant watermelon varieties (Kucharek et al. 1992). Increases of soil levels of the third race (race 2), which is highly aggressive, have been shown to follow monocultures of resistant varieties of watermelons in Florida. Long rotations are required to manage fusarium wilt, even when using resistant varieties (Hopkins, Lobinske, and Larkin 1992).

The disease causes wilting and decline, which may occur in entire plants or in individual runners. Most commonly, 
the entire plant wilts quickly without yellowing and then turns brown and dies. A longitudinal cut in the lower stem of infected plants will reveal yellow, orange, or brownish streaks in the vascular tissue. In Florida, the disease usually occurs before fruit set. Infection rarely occurs at temperatures above $86^{\circ} \mathrm{F}\left(30^{\circ} \mathrm{C}\right)$, and optimum temperature for infection is about $80^{\circ} \mathrm{F}\left(27^{\circ} \mathrm{C}\right)$ (Roberts and Kucharek 2005; Kucharek et al. 1992).

\section{ANTHRACNOSE}

In the past, anthracnose (caused by Colletotrichum orbiculare) was a serious disease in Florida watermelon production, but the use of resistant varieties has limited its impact. Three races of anthracnose are known (races 1,2 , and 3), and some varieties show resistance to some races but not others. Anthracnose race 2 has caused serious damage to watermelons in the southeastern United States. When it does occur, anthracnose can destroy the entire field if not controlled, particularly after several days of warm, rainy weather (Bertelsen et al. 1994; Roberts and Kucharek 2005).

All aboveground plant parts may be affected by this fungal disease, and infected plants may die under severe conditions. Early symptoms of the disease include angular, brown to black leaf spots on older leaves, similar in appearance to those of gummy stem blight or downy mildew. Tan, ovalshaped lesions may appear on the stems. Spores from leaf and stem lesions later infect the fruit, producing sunken, water-soaked spots. Disease development is greatest during humid, rainy weather. Spores are spread by wind, splashing rain, people, and machinery. The fungus, which can be seedborne, survives between crops on infected plant debris and volunteer plants (Bertelsen et al. 1994; Roberts and Kucharek 2005; Maynard and Hopkins 1999).

\section{Chemical Control}

In 2010, Florida growers applied fungicides totaling 352,100 pounds of active ingredient to $94 \%$ of the state's watermelon acreage. During the years usage data was collected, $86 \%-96 \%$ of watermelon acreage was treated with fungicides each year, with total annual usage ranging from 205,800 to 352,100 pounds of active ingredient (USDA/NASS 2011c). Older published applied fungicides on Florida watermelons are azoxystrobin, chlorothalonil, copper hydroxide, mancozeb, copper sulfate, fosetyl-Al, mefenoxam, sulfur, thiophanate-methyl, trifloxystrobin, dimethomorph, pyraclostrobin, and zoxamide. Other recently registered fungicides for use on Florida watermelons are acibenzolar-s-methyl, potassium phosphite, potassium phosphate, potassium silicate, hydrogen dioxide, potassium bicarbonate, boscalid, tebuconazole, penthiopyrad, 1,3-dichloropropene, chloropicrin, difenoconazole, fluopyram, polyoxin-D zinc salt, fluopicolide, propamocarb hydrochloride, triflumizole, quinoxyfen, myclobutanil, cyazofamid, fenamidone, mandipropamid, kresoxim-methyl, cyprodinil, cymoxanil, fludioxonil, famoxadone, and laminarin (USDA 2011a; CDMS 2013).

\section{MANCOZEB}

Mancozeb is an ethylene (bis) dithiocarbamate (EBDC) fungicide used prophylactically primarily for managing downy mildew. It may also be effective in managing gummy stem blight, anthracnose, alternaria leaf spot, and cercospora leaf spot (Vallad et al. 2010). Mancozeb may be applied up to 5 days before harvest (pre-harvest interval $=5$ days), and the REI under the WPS is 24 hours. A maximum of 19.2 pounds of active ingredient (or EBDC fungicide in general) may be applied per acre for each crop (CDMS 2013).

In 2010, Florida growers applied an average of 1.39 pounds of active ingredient per application to $91 \%$ of their watermelon acreage, an average of 5.4 times. Total usage was 175,700 pounds of active ingredient. During the years usage data was collected, Florida watermelon growers have applied mancozeb at an average rate ranging from 0.91 to 1.56 pounds of active ingredient per acre at each application to $20 \%-91 \%$ of their watermelon acreage. Growers have made an average of 3.8-7.2 applications per year, totaling $81,500-244,900$ pounds of active ingredient annually (USDA/NASS 2011c).

\section{CHLOROTHALONIL}

Chlorothalonil is a broad-spectrum chloronitrile fungicide used as a protectant on Florida watermelons. Growers primarily apply it to manage gummy stem blight, downy mildew, and leaf spot, although it may also be effective in managing anthracnose and alternaria leaf spot (Vallad et al. 2010). Chlorothalonil may be applied up to harvest, and the REI under the WPS is 12 hours. It should not be applied to watermelons under conditions conducive to sunburn (e.g., high levels of heat and sunlight, drought, or poor vine canopy).

In 2010, Florida growers applied an average of 1.48 pounds of active ingredient per application to $82 \%$ of their watermelon acreage, an average of 4.1 times. Total usage was 135,800 pounds of active ingredient. During the years usage data was collected, Florida watermelon growers have applied chlorothalonil at an average rate ranging from 1.26 to 1.72 pounds of active ingredient per acre at 
each application to $45 \%-86 \%$ of their watermelon acreage. Growers have made an average of 2.6-4.1 applications per year, totaling 51,600-160,900 pounds of active ingredient annually (USDA/NASS 2011c).

\section{AZOXYSTROBIN}

Azoxystrobin is a member of the strobilurin class of fungicides. It is used to manage anthracnose as well as gummy stem blight, downy mildew, and leaf spot (Vallad et al. 2010). Azoxystrobin may be applied up to one day before harvest, and the REI under the WPS is four hours.

In 2010, Florida growers applied an average of 0.13 pounds of active ingredient per application to $28 \%$ of their watermelon acreage, an average of 1.7 times. Total usage was 1,500 pounds of active ingredient. During the years usage data was collected, watermelon growers in Florida have applied azoxystrobin at an average rate ranging from 0.12 to 0.20 pounds of active ingredient per acre at each application to $28 \%-34 \%$ of their watermelon acreage. Growers have made an average of 1.1-1.7 applications per year, totaling $1,400-2,200$ pounds of active ingredient annually (USDA/ NASS 2011c).

\section{COPPER HYDROXIDE}

Watermelon growers in Florida use copper hydroxide to manage downy mildew and bacterial fruit blotch (Vallad et al. 2010). Copper hydroxide may be applied up to the day of harvest, but the REI under the WPS is 24 hours.

In 2010, Florida growers applied an average of 0.58 pounds of active ingredient per application to $24 \%$ of their watermelon acreage, an average of 3.8 times. Total usage was 14,100 pounds of active ingredient. During the years usage data was collected, watermelon growers in Florida have applied copper hydroxide at an average rate ranging from 0.50 to 1.09 pounds of active ingredient per acre at each application to $6 \%-34 \%$ of their watermelon acreage. Growers have made an average of 2.3-3.8 applications per year, totaling 9,500-18,800 pounds of active ingredient annually (USDA/NASS 2011c).

\section{Cultural Control}

Incidence of viral diseases can be reduced on fall-planted watermelons by planting as far as possible from fields planted to cucurbits the preceding spring (Hochmuth and Elmstrom 1992). In addition, removing volunteer watermelon and other cucurbit plants from around the field can further reduce the spread of viruses (Roberts and Kucharek 2005). Weeds should be removed before watermelons are planted because weed senescence during the growing season may cause insect pests, such as aphids, thrips, and whiteflies, to move into the crop. This practice is useful principally in South Florida. Researchers have been investigating the use of reflective mulches to repel aphids from landing on watermelons. Additionally, some growers are using purified mineral oil sprays (stylet oil) to prevent virus transmission.

In addition to reducing potential sources of viruses, weed management can improve efficiency of fungicide sprays because weed presence can interfere with adequate spray coverage. Weeds near watermelon plants tend to increase crop moisture, which is necessary for the germination of fungal spores that initiate disease development. Therefore, properly managing weeds in and around the field is an essential component of overall disease management in watermelons (Roberts and Kucharek 2005).

Using resistant varieties and rotating land that has been out of watermelon production for at least eight years have been the primary means of managing fusarium wilt of watermelon in Florida. Even when using resistant varieties, an interval of at least $4-5$ years between watermelon plantings should be followed. Rotation also helps to manage gummy stem blight, seedling blights, and fusarium wilt. The best rotation crops for watermelons are grasses, such as corn or pasture grasses. Growers had been using land that was previously used for pasture for watermelon production, but the declining availability of land, particularly in South Florida, has limited this practice. Ways to reduce fusarium wilt in Florida watermelon include maintaining soil $\mathrm{pH}$ between 6.5 and 7.5 by liming, using nitrate rather than ammonium forms of nitrogen fertilizer, using healthy transplants, removing or turning under crop residues after harvest, and delayed thinning (Bertelsen et al. 1994; Hochmuth et al. 1997; Spreen et al. 1995; Mitchell, Martin, and Charudattan 1994).

Watermelon varieties with resistance to anthracnose race 1 and varieties with resistance to fusarium wilt are available in Florida (Maynard 1992). Most varieties in use today carry resistance to both fusarium wilt and anthracnose. However, that resistance is not complete, with some plants always being susceptible. Researchers in Florida are developing two transgenic varieties of virus-resistant seedless watermelons (Gray n.d.).

The minimum recommended rotation time for gummy stem blight is at least two and preferably four years. In addition to crop rotation, turning under old crop debris helps to manage gummy stem blight. Spores serving as the primary inoculum of the disease survive on watermelon, 
muskmelon, cucumber, squash, and pumpkin debris, and deep plowing prevents those spores from being spread by wind into active watermelon fields. Deep plowing also helps to manage southern blight and leaf spots because it buries the pathogens that cause these diseases, inhibiting their movement. Furthermore, using drip irrigation and planting on a well-drained field with good air circulation can minimize periods of leaf wetness that intensify disease development (Roberts and Kucharek 2005).

Phytophthora blight is most effectively managed by controlling excess water (planting in well-drained fields and employing appropriate irrigation practices). Because the fungus can spread in contaminated soil, workers should wash hands and shoes before moving from one field to another (Roberts and McGovern 1998).

Bacterial fruit blotch can be seedborne, so it is important to use only seed free of bacterial fruit blotch inoculum. Researchers evaluating several seed treatments to eliminate the fruit blotch bacterium determined that fermentation of seeds in watermelon juice and debris followed by washing and drying reduced seed transmission to less than $1 \%$. The most effective treatment was found to be fermentation of seeds for 24-48 hours, followed by soaking of washed seeds in $1 \%$ hydrogen chloride or calcium hypochlorite for 15 minutes before washing and drying (Hopkins, Cucuzza, and Watterson 1996). Most companies selling watermelon seed now test their seed lots to declare them free of the fruit blotch pathogen but do not guarantee complete absence of the pathogen. Changes in the ways seeds are handled and tested have led to great increases in the price of watermelon seeds for the grower (Latin and Hopkins 1995).

Several cultural practices other than crop rotation can also help to manage damping-off (seedling blight), including turning under or composting crop residues, avoiding planting in cool soils, and using healthy transplants or seed treatments. Furthermore, transplants should not be set too deeply, and they should not be exposed to production fields during transport, which can be avoided by using covers on transport vehicles (Roberts and Kucharek 2005).

\section{Biological Control}

Research on soils suppressing various plant pathogens has been conducted in Florida for years. The development of soils suppressive to fusarium wilt of watermelon has been found to be stimulated by monoculture production of the variety 'Crimson Sweet' (Mitchell, Martin, and Charudattan 1994). As a result of inducing fusarium wilt-suppressive soils, successive planting of 'Crimson Sweet' watermelons on the same land reduces disease severity.

'Crimson Sweet' is the only variety that has been found to promote this buildup of suppressiveness. However, suppressive soils promoted by 'Crimson Sweet' monocultures effectively reduce fusarium wilt on all other varieties. The factor responsible for the suppressive soil was shown to be sensitive to fumigation with methyl bromide and 30-minute treatment with moist heat $\left(158^{\circ} \mathrm{F}\right.$ or $\left.70^{\circ} \mathrm{C}\right)$ (Hopkins, Larkin, and Elmstrom 1987). In studies to determine the specific cause of fusarium wilt suppression in soils planted successively to 'Crimson Sweet' watermelons, researchers found the 'Crimson Sweet' variety to favor the growth of nonpathogenic populations of indigenous $F$. oxysporum and of overall populations of nonpathogenic bacteria (Larkin, Hopkins, and Martin 1993). Nonpathogenic populations of the fungus have been determined to be the principal antagonists responsible for the suppressive nature of the soils. Further studies of these antagonists are under way, with a long-term goal of developing them as biological control agents (Larkin, Hopkins, and Martin 1996). However, no commercially feasible biological control agents are currently available for watermelon diseases.

\section{Postharvest Decays and Their Management}

When postharvest diseases of watermelons occur, the most common are black rot and stem end rot. Bruising during shipment can reduce quality and contribute to postharvest decay. Decay organisms require entry points, such as mechanical damage or weakened tissue. They can also enter the fruit through contaminated water or other infected plant parts. Postharvest decay is minimized by following appropriate cultural practices, minimizing handling during harvest and shipping, and managing temperature during shipping and storage (Rushing 2004).

Black rot is a significant post-harvest disease of watermelons. By the time infested fruits arrive at the market, they have developed green to black spots on the rind, which enlarge as the decay enters the watermelon interior. Black rot can leave the fruit susceptible to secondary bacterial and fungal infections (Rushing 2004). After infection occurs in the field, the disease can develop during shipment, and it is more severe under warm, humid conditions (Maynard and Hopkins 1999).

Stem end rot begins as the stem shrivels and turns brown, and the infection enters the fruit at the point of attachment with the stem. The watermelon tissue becomes 
water-soaked and softened, with accompanying browning and shriveling. When the disease is severe, black pycnidia (spores) and the gray mycelium (body of the fungus) can be seen (Rushing 2004).

These diseases can occur, but generally post-harvest disease problems on watermelons in Florida are minimal unless mechanical damage occurs. The move to ship watermelons in pallet-sized bins, rather than loading in bulk, should reduce postharvest disease incidence because bulk loading entails greater potential for bruising and cracking (Rushing 2004).

\section{Nematode Management}

\section{Nematode Pests}

Nematodes are microscopic roundworms living in the soil that feed on the plants' roots and damage the tissue. Watermelons are highly susceptible to nematode injury, as are all cucurbits. Damage can be particularly severe on sandy soil, the predominant soil type in Florida watermelon production. Typical aboveground symptoms of nematode feeding on watermelon roots include stunting, premature wilting, leaf yellowing, and related symptoms characteristic of nutrient deficiencies. Stunting and poor stand developments tend to occur in patches throughout the field as a result of the irregular distribution of nematodes in the soil. Damage and yield loss are directly related to the level of infestation by nematodes. The principal nematode pests on watermelons in Florida are root-knot (Meloidogyne spp.) and sting (Belonolaimus longicaudatus). Reniform nematodes (Rotylenchulus spp.) can be a problem in South Florida (Noling 2012a; Noling 2012b).

\section{ROOT-KNOT NEMATODE}

All of the common species of root-knot nematodes (Meloidogyne spp.), including M. incognita, M. javanica, and $M$. arenaria, can damage watermelons in Florida. However, root-knot damage has historically been low in North and Central Florida because of growing watermelons in old pasture land or after long grass rotations to reduce damage from fusarium wilt (Noling 2012a; Noling 2012b). In southwest Florida, the lack of reported damage from root-knot nematodes is attributed to the use of methyl bromide.

Root-knot nematodes enter the host plant root as second stage juveniles and settle within the root to establish a feeding site. At the feeding site, secretions from the nematode cause the surrounding plant cells to enlarge and multiply, producing the characteristic galls associated with root-knot attack. On watermelons, galls measuring from $1 / 8$ to $1 / 4$ inch $(0.3-0.6 \mathrm{~cm})$ in diameter begin to form as soon as the roots are infested. As more nematodes enter the root and feeding continues, the galls fuse to form large tumors on the roots. The developing female molts several times in the root before developing into a swollen, pear-shaped adult. The adult may live in the host plant for several months, laying hundreds to several thousand eggs that are released into the soil. Low temperatures or very dry soil conditions can cause eggs to hatch more slowly (Noling 2012b; Stokes 1972; Crow and Dunn 2012).

Root deformation and injury caused by root-knot nematodes reduce root area and interfere with water and nutrient uptake. Resulting symptoms include stunting, wilting, chlorosis, and yield loss. In addition to expending the plant's resources, the gall tissue is more susceptible to secondary infections such as root rots (Stokes 1972).

\section{STING NEMATODE}

Sting nematodes (Belonolaimus spp.) are ectoparasites, remaining outside the plant root and feeding superficially at or near the root tip by penetrating the root deeply with their long needle-like mouthparts (stylets). Affected root tips turn yellow and later necrotic, with cavities forming and the root tip swelling slightly. Damage from sting nematode feeding inhibits root elongation and causes roots to form tight mats and appear swollen, resulting in a "stubby root" or "coarse root" appearance. Under severe infestations, new root growth is killed in a way that resembles fertilizer salt burn (Noling 2012b; Crown and Dunn 2012; Esser 1976).

Sting nematodes are especially damaging to seedlings and transplants. In North Florida, they are most abundant in April and May. Sting nematodes prefer sandy soils (with $84 \%-94 \%$ sand) and are most abundant in the upper 12 inches $(30 \mathrm{~cm})$. Optimum soil temperature for this nematode is $77^{\circ} \mathrm{F}-90^{\circ} \mathrm{F}\left(25^{\circ} \mathrm{C}-32^{\circ} \mathrm{C}\right)$, and optimum soil moisture is about 7\% (Noling 2012b; Crow and Dunn 2012; Esser 1976).

\section{RENIFORM NEMATODE}

Reniform nematodes (Rotylenchulus spp.) feed in the plant root, entering as second-stage juveniles and settling at a feeding site. By releasing growth regulators into the surrounding tissue, the nematodes cause the plant to redirect nutrients to the cells around the feeding site, using energy and disrupting the vascular system. However, they do not produce galls on the root tissue (Crow and Dunn 2012; Esser 1976). 


\section{Chemical Control}

Oxamyl and dichloropropene are the principal pesticides used to manage nematodes on Florida watermelons. An additional nematicide registered for use on watermelons is metam sodium (USDA/NASS 2011b; CDMS 2013).

Watermelon is usually grown as a double crop behind tomatoes or peppers, and fumigants (1,3-dichloropropene and chloropicrin) are applied to the first crop and not to the watermelons. However, growers might apply reduced rates of those fumigants to the watermelon when nematodes are a problem under new plastic mulch (Noling 2013).

\section{Cultural Control}

Crop rotation is an important cultural management tool and is frequently used by North Florida watermelon growers. These growers often plant watermelons on land after a long rotation of poor or non-host pasture grass. However, as new land or pasture land is increasingly unavailable, the rotation time is correspondingly shortened or eliminated, and increased nematode problems have been observed. When the use of cover crops or rotational crops is considered, the choice of crop depends on which nematode populations are present. Several grasses, including corn, sorghum, bahiagrass, bermudagrass, and pangola digitgrass, have successfully reduced populations of root-knot nematodes, but other nematode species may increase on those crops. A nematode assay should be performed to determine the species of nematodes in the field (Spreen et al. 1995).

Several other cultural measures also help to manage nematodes in watermelon production. Rapidly destroying or removing crop roots after harvest reduces the material for nematodes to feed and reproduce on. In addition, maintaining weed-free fields between crops and practicing frequent cultivations during the season to reduce nematode-harboring weeds further eliminate the source of continued infestation. In most instances, it is not possible to manage nematodes without simultaneously implementing an effective weed management program. Also, using strong, nematode-free transplants gives watermelon plants a healthy start and may enhance their ability to tolerate nematode attack (Spreen et al. 1995).

\section{Biological Control}

Numerous predators and parasites of nematodes are known, including fungi, bacteria, other nematodes, and mites. Many of these have been found in most of the surveyed soils. Attempts have been made to use organic amendments to create soil conditions more conducive to developing these nematode antagonists. Results of organic amendment studies have been controversial, in part because the amendments can affect plant growth directly, exclusive of any effect on the nematode population. The effectiveness of organic amendments depends on numerous factors, and these combined effects need further study (McSorley 1999; Dickson et al. 1994).

Mass production and field release of nematode antagonists have also been investigated. The bacterium Pasteuria penetrans is the most promising biological control agent, particularly for root-knot nematodes. Studies of the Pasteuria species biology have shown its potential as an effective management tool for nematodes, but two major problems make it impractical for commercial use. Most Pasteuria spp. isolates are very host specific, so numerous products would have to be developed for use against the range of nematode pests affecting agricultural crops. In addition, methods for low-cost mass rearing of the bacteria, which require a full understanding of its nutrient requirements, have not yet been developed. P. penetrans is commonly found in soils throughout Florida, and researchers are also investigating its soil ecology to find ways to increase its presence in soils. While Pasteuria has shown promise in reducing nematode populations, its use as a biological control agent for nematode management is still in the research stage (McSorley 1999; Dickson et al. 1994; Hewlett et al. 1994; Chen and Dickson 1998).

\section{Weed Management}

\section{Weed Pest}

Competition from weeds can be severe in watermelon production because of the slow growth rate of the crop early in the season, its low planting density, and low vining habit. Early season weed management is essential. Weeds late in the season can reduce the efficiency of harvest and incur losses, but yield loss from competition does not occur when weeds emerge later in the growth of the watermelon crop. When weed populations are high, watermelon yield can be reduced by $50 \%-100 \%$ without weed management. When weeds are managed, the potential yield loss from weed competition still reaches an estimated 15\% (Hochmuth et al. 1997; Stall 1992; Dittmar and Stall 2012; Locascio et al. 1989).

A variety of weeds are problematic for Florida watermelon producers, including nutsedges (yellow and purple), grasses (for example, crabgrass, goosegrass, and Texas panicum), and broadleaf weeds, such as bristly starbur, Florida pusley, and purslane. Amaranths are particularly troublesome, and 
nutsedge is becoming a major problem. The specific weeds present will vary by region in the state and by previous land use. For example, on recently cleared land or land in grass production for a long period, weed pressure is usually low. On the other hand, pressure from broadleaf and grass weeds can be high on recently cultivated land (Stall 1992).

\section{NUTSEDGE}

Two nutsedges (Cyperus spp.), yellow nutsedge (C. esculentus) and purple nutsedge (C. rotundus), are among the greatest weed problems in Florida watermelon production and will pose a greater dilemma without the use of methyl bromide. Both of these perennial sedges are found in disturbed habitats throughout Florida and the southeast United States. Yellow nutsedge may produce some seed but reproduces primarily by rhizomes and tubers. The parental plant develops rhizomes, which end in bulbs or tubers that produce new plants. Tuber production is favored by low nitrogen levels and high temperatures $\left(80^{\circ} \mathrm{F}-91^{\circ} \mathrm{F}\right.$ or $27^{\circ} \mathrm{C}-$ $33^{\circ} \mathrm{C}$ ). The plant is tolerant of high soil moisture but does not tolerate shade. Purple nutsedge can reproduce from tubers when conditions are harsh, making it difficult to control. Unlike yellow nutsedge rhizomes, purple nutsedge rhizomes growing off the parent plant produce new plants in a series (called "tuber-chains"). The plant also reproduces by seed to a limited degree. Although purple nutsedge is also intolerant of shade, it can survive a wide range of environmental conditions. It can grow well in nearly all soil types and in a range of soil moisture, soil $\mathrm{pH}$, and elevation. Purple nutsedge is also able to survive extremely high temperatures (Miller et al. 1975).

Recent research in Florida has shown that the presence of 25 yellow nutsedge plants per square meter (2.32 per square foot) in the watermelon bed throughout the season reduces yield by $98 \%$, and six yellow nutsedge plants per square meter ( 0.56 per square foot) reduces yield by $20 \%$. Nutsedge plants emerging at least five weeks after watermelons have no effect on watermelon yield (Stall 1999).

\section{AMARANTH}

Amaranths (Amaranthus spp.), called pigweeds, are summer annual broadleaf herbs with erect stems that can grow to 6.5 feet $(2 \mathrm{~m})$ tall. Several species of amaranth are present in Florida, but the main amaranth weeds in watermelons are smooth pigweed (Amaranthus hybridus) and spiny amaranth (Amaranthus spinosus). Amaranths or pigweeds reproduce solely by seed, producing very small, dark seeds. Smooth pigweed flowers from July to November, and spiny amaranth flowers from June to October. They prefer open areas with bright sunlight (Miller et al. 1975; Lorenzi and Jeffery 1987).

Research in Florida has shown that the presence of six smooth pigweed plants between watermelon plants throughout the whole season will reduce watermelon yield by $100 \%$. However, watermelon plants maintained free of emerging smooth pigweed for four weeks suffer no yield loss as a result of competition from smooth pigweed plants emerging after that time. Also, a weed-free period of approximately three weeks after the crop's emergence results in a $10 \%-20 \%$ yield loss. In addition, $10 \%$ yield loss results if smooth pigweed that emerges at the same time as the watermelon is removed after five days, and watermelon suffers 20\% yield loss after two weeks (Stall 1999; Terry et al. 1997).

\section{CRABGRASS}

Crabgrasses (Digitaria spp.) are annual grass plants that reproduce mainly by seed, but also by spreading and rooting of stems at the base. They germinate during the summer, flowering from June or July to October and quickly establish clumps. Crabgrass thrives in moist soil (Miller et al. 1975; Lorenzi and Jeffery 1987). A study of competition from large crabgrass in watermelon production demonstrated that when the weed emerged at least six weeks after watermelon emergence, no reduction of yield or fruit quality occurred. However, watermelon yield was reduced by $7 \%$ for every week once large crabgrass was present, and yield loss from competition throughout the whole growing season reached more than 70\% (Stall 1999).

\section{GOOSEGRASS}

Goosegrass (Eleusine indica) is similar in appearance to crabgrass, but grows more densely. It is also a summer annual and prefers sunny, moist conditions. Reproducing by seed, it flowers from July to October (Miller et al. 1975; Lorenzi and Jeffery 1987). As few as 24 goosegrass plants per 30 feet $(9.1 \mathrm{~m})$ of row can reduce watermelon yield (Stall 1999).

\section{TEXAS PANICUM}

Texas panicum (Panicum texanum) is primarily a problem in South Florida. A summer annual with erect stems, the plant produces large seeds and also roots at the nodes (Miller et al. 1975).

\section{BRISTLY STARBUR}

Bristly starbur (Acanthospermum hispidum) is present only in the northern part of the state, and it is becoming a major problem for watermelon producers in that region. 
This highly competitive weed also appears to be spreading southward. Bristly starbur received its common name because of the bristly appearance of the flat, triangular fruits, several of which are clumped at each head. Fruits, stems, and leaves are all densely covered with hairs. Bristly starbur produces abundant seed until the plant freezes in the fall. Deep plowing is thought to aid in reducing its population, because seeds buried below 3 inches $(7.5 \mathrm{~cm})$ in the soil have been found to lose viability after three years (Dittmar and Stall 2012).

\section{FLORIDA PUSLEY}

Florida pusley (Richardia scabra) is a loosely branched annual that stands erect or lies flat on the ground. Its hairy stems and oppositely arranged leaves are often rough in texture, particularly along the main veins. The plant is only found in Central and North Florida and is often mixed with Brazilian pusley (R. brasiliensis). Florida pusley reproduces by seed and blooms in any month in the absence of frost (Dittmar and Stall 2012).

\section{PURSLANE}

Purslane (Portulaca oleracea) is a broadleaf summer annual with a single taproot. Multiple branched, purplish-red stems arise from the taproot and often form large mats. Clusters of small leaves are found at the end of its branches. The plant reproduces by seed, flowering from August to October. Being resistant to drought, it is difficult to kill. However, it is susceptible to frost injury (Miller et al. 1975; Lorenzi and Jeffery 1987).

\section{Chemical Control}

In 2010, Florida growers applied herbicides totaling 4,500 pounds of active ingredient to $18 \%$ of the state's watermelon acreage. During the years usage data was collected, $14 \%-31 \%$ of the state's watermelon acreage was treated with herbicides each year, with total annual usage ranging from 3,900 to 18,300 pounds of active ingredient (USDA/ NASS 2011c). Older herbicides registered for watermelon are sethoxydim, ethalfluralin, glyphosate, halosulfuron, paraquat, trifluralin, clomazone, clethodim, DCPA, pelargonic acid, and bensulide. Herbicides more recently labeled for the use on watermelon are carfentrazone-ethyl, oxyfluorfen, pyraflufen-ethyl, ammoniated soap of fatty acids, d-limonene, metam-sodium, metam-potassium, terbacil, cinnamon and clove oil (USDA/NASS 2011b; CDMS 2013).

When applying herbicides, it is essential to follow label directions. Watermelons have a narrow range of tolerance for most herbicides, and incorrect application can easily damage the crop (Dittmar and Stall 2012).

\section{Cultural Control}

Adequate management of weeds in Florida watermelon production cannot be obtained with herbicides alone. Weed management in watermelon requires a combination of tactics, including good field preparation and cultivation (Hochmuth et al. 1997; Locascio et al. 1989). Because of the wider row spacing in watermelon production, between-row cultivation is more common for watermelons than for other cucurbits such as cucumbers and cantaloupe. Cultivation must be shallow to avoid injuring crop roots, and it is limited to the first 4-5 weeks after emergence. Mechanical cultivation is impractical after that time due to the running of vines, and it is no longer cost-effective because yields are reduced by weed competition primarily during the early weeks (Stall 1999; Terry et al. 1997). Used early in the season, mechanical control (disking, hoeing, mowing, or cultivation) is an important part of the overall weed management program for watermelons.

Using appropriate water and nutrient management practices to allow a healthy crop to better compete with weed species is also important (Spreen et al. 1995; Locascio et al. 1989). Fallow treatments before planting are also effective in reducing weed populations. Weeds are disked under several times after emergence but before propagation, and the mechanical fallowing is often combined with herbicide treatments applied two weeks before disking (Stall 1999). Using plastic mulch is an important management tool for all weeds except nutsedges, which can grow through the mulch (Spreen et al. 1995).

\section{References}

Adlerz, W. C. 1987. "Cucurbit Potyvirus Transmission by Alate Aphids (Homoptera: Aphididae) Trapped Alive." Journal of Economic Entomology 80: 87-92.

Adlerz, W. C. 1978. "Secondary Spread of Watermelon Mosaic Virus 2 by Anuraphis middletonii." Journal of Economic Entomology 71: 531-533.

Bertelsen, D., J. Harwood, F. Hoff, H. Lee, A. Perez, S. Pollack, A. Somwaru, and G. Zepp. 1994. Watermelons: An Economic Assessment of the Feasibility of Providing MultiplePeril Crop Insurance. USDA Economic Research Service, in cooperation with the University of California for the Federal Crop Insurance Corporation. 
Brinen, G. 2003. Vegetable Extension agent, UF/IFAS Extension Alachua County, in communication with the author.

Capinera, J. L. 2011. Banded Cucumber Beetle, Diabrotica balteata LeConte (Insecta: Coleoptera: Chrysomelidae). EENY-093. Gainesville: University of Florida Institute of Food and Agricultural Sciences. http://edis.ifas.ufl.edu/ in 250 .

Castineiras, A., R. M. Baranowski, and H. Glenn. 1997. "Distribution of Neoseiulus cucumeris (Acarina: Phytoseiidae) and Its Prey, Thrips palmi (Thysanoptera: Thripidae) within Eggplants in South Florida." Florida Entomologist 80 (2): 211-217. http://www.fcla.edu/FlaEnt/fe802.htm.

Castineiras, A., R. M. Baranowski, and H. Glenn. 1996. "Temperature Response of Two Strains of Ceranisus menes (Hymenoptera: Eulophidae) Reared on Thrips palmi (Thysanoptera: Thripidae)." Florida Entomologist 79 (1): 13-19. http://www.fcla.edu/FlaEnt/fe791.htm.

Castineiras, A., J. E. Peña, R. Duncan, and L. Osborne. 1996. "Potential of Beauveria bassiana and Paecilomyces fumosoroseus (Deuteromycotina: Hyphomycetes) as Biological Control Agents of Thrips palmi (Thysanoptera: Thripidae)." Florida Entomologist 79 (3): 458-461. http:// journals.fcla.edu/flaent/issue/view/3554.

Chen, Z. X., and D. W. Dickson. 1998. "Review of Pasteuria penetrans: Biology, Ecology, and Biological Control Potential." Journal of Nematology 30 (3): 313-340.

Crop Data Management Systems, Inc. (CDMS). 2013. CDMS Label Search. http://premier.cdms.net/webapls/.

Crow, W. T., and R. A. Dunn. 2012. Introduction to Plant Nematology. ENY-016. Gainesville: University of Florida Institute of Food and Agricultural Sciences. http://edis.ifas. ufl.edu/ng006.

Dickson, D. W., M. Oostendorp, R. M. Giblin-Davis, and D. J. Mitchell. 1994. "Control of Plant-Parasitic Nematodes by Biological Antagonists." In Pest Management in the Subtropics, Biological Control: A Florida Perspective, edited by D.

Rosen, F. D. Bennett, and J. L. Capinera, 575-601. Andover, UK: Intercept.

Dittmar, P. J., and W. M. Stall. 2012. Weed Control in Cucurbit Crops (Muskmelon, Cucumber, Squash, and Watermelon). HS190. Gainesville: University of Florida
Institute of Food and Agricultural Sciences. http://edis.ifas. ufl.edu/wg029.

Dixon, W. N. 1988. White-Fringed Beetles, Graphognathus spp. Entomology Circular 309. Gainesville, FL: FDACS, Division of Plant Industry.

Esser, R. P. 1976. Sting Nematodes, Devastating Parasites of Florida Crops. Nematology Circular No. 18. Gainesville: FDACS, Division of Plant Industry.

Florida Department of Agriculture and Consumer Services (FDACS). 2012. Florida Agriculture by the Numbers. Tallahassee, FL: FDACS. http://www.florida-agriculture.com/ brochures/P-01304.pdf.

Frank, J. H. 1994. "Biological Control of Pest Mole Crickets." In Pest Management in the Subtropics Biological Control: A Florida Perspective, edited by D. Rosen, F. D. Bennett, and J. L. Capinera, 343-352. Andover, UK: Intercept.

Frank, J. H., T. R. Fasulo, and D. E. Short. 1998. "Alternative Methods of Mole Cricket Control." In Mole Cricket Knowledgebase. Gainesville: University of Florida Institute of Food and Agricultural Sciences.

Frankle, W. G., D. L. Hopkins, and R. E. Stall. 1993. "Ingress of the Watermelon Fruit Blotch Bacterium into Fruit." Plant Disease 77: 1090-1092.

Gevens, A. J., P. D. Roberts, R. J. McGovern, and T. A. Kucharek. 2011. Vegetable Diseases Caused by Phytophthora capsici in Florida. SP159. Gainesville: University of Florida Institute of Food and Agricultural Sciences. http://edis.ifas. ufl.edu/vh045.

Gray, D. J. n.d. Transgenic Seedless Watermelon Resistant to Viruses. T-Star Caribbean Program in Tropical/Subtropical Agricultural Research.

Hewitt, T. D. 1996. "Economic Considerations for Direct Seeding vs. Transplanting of Watermelons." Citrus \& Vegetable Magazine 60 (7): 38-40.

Hewlett, T. E., R. Cox, D. W. Dickson, and R. A. Dunn. 1994. "Occurrence of Pasteuria spp. in Florida." Supplement to the Journal of Nematology 26 (4S): 616-619.

Hochmuth, G. 1992. "Fertilizer Management for Watermelons." In Watermelon Production Guide for Florida, edited by D. N. Maynard. SP-113. Gainesville: University of Florida Institute of Food and Agricultural Sciences. 
Hochmuth, G., and G. Elmstrom. 1992. "Cultural Practices." In Watermelon Production Guide for Florida, edited by D. N. Maynard. SP-113. Gainesville: University of Florida Institute of Food and Agricultural Sciences.

Hochmuth, G. J., W. M. Stall, T. D. Hewitt, and K. C. Ruppert. 1997. Alternative Opportunities for Small Farms: Watermelon Production Review. RF-AC029. Gainesville: University of Florida Institute of Food and Agricultural Sciences.

Hochmuth, R. 2003. Vegetable Extension agent, UF/ IFAS Suwannee Valley Research and Education Center, in communication with the author.

Hopkins, D. 1991. "Chemical Control of Bacterial Fruit Blotch of Watermelon." Proceedings of the Florida State Horticultural Society 104: 270-272.

Hopkins, D. 2003. Plant pathologist, UF/IFAS Central Florida Research and Education Center, in communication with the author.

Hopkins, D., J. D. Cucuzza, and J. C. Watterson. 1996. "Wet Seed Treatment for the Control of Bacterial Fruit Blotch of Watermelon." Plant Disease 80: 529-532.

Hopkins, D. L., R. P. Larkin, and G. W. Elmstrom. 1987. "Cultivar-Specific Induction of Soil Suppressiveness to Fusarium Wilt of Watermelon." Phytopathology 77: 607-611.

Hopkins, D. L., R. J. Lobinske, and R. P. Larkin. 1992. "Selection for Fusarium oxysporum f.sp. niveum Race 2 in Monocultures of Watermelon Cultivars Resistant to Fusarium Wilt." Phytopathology 82: 290-293.

Johnson, F. A. 1992. “Pollination.” In Watermelon Production Guide for Florida, edited by D. N. Maynard. SP-113. Gainesville: University of Florida Institute of Food and Agricultural Sciences.

Johnson, F. A., D. E. Short, and J. L. Castner. 2005. Sweetpotato/Silverleaf Whitefly Life Stages and Damage. SP-90. Gainesville: University of Florida Institute of Food and Agricultural Sciences.

Kucharek, T., J. P. Jones, D. Hopkins, and J. Strandberg. 1992. Some Diseases of Vegetable and Agronomic Crops Caused by Fusarium in Florida. Circular 1025. Gainesville: University of Florida Institute of Food and Agricultural Sciences.
Larkin, R. P., D. L. Hopkins, and F. N. Martin. 1993. “Effect of Successive Watermelon Plantings on Fusarium oxysporum and Other Microorganisms in Soils Suppressive and Conducive to Fusarium Wilt of Watermelon." Phytopathology 83: 1097-1105.

Larkin, R. P., D. L. Hopkins, and F. N. Martin. 1996. "Suppression of Fusarium Wilt of Watermelon by Nonpathogenic Fusarium oxysporum and Other Microorganisms Recovered from a Disease-Suppressive Soil." Phytopathology 86: 812-819.

Latin, R. X., and D. L. Hopkins. 1995. "Bacterial Fruit Blotch of Watermelon: The Hypothetical Exam Question Becomes Reality." Plant Disease 79 (8): 761-765.

Locascio, S. J., W. M. Stall, S. M. Olson, and C. S. Vavrina. 1989. "Watermelon Production as Influenced by Herbicide Combination and Cultivation." Proceedings of the Florida State Horticultural Society 102: 332-335.

Lorenzi, H. J., and L. S. Jeffery. 1987. Weeds of the United States and Their Control. New York: Van Nostrand Reinhold Company.

Maynard, D. 2003. Horticultural scientist, UF/IFAS Gulf Coast Research and Education Center, in communication with the author.

Maynard, D. N. 1996. Growing Seedless Watermelon. Gainesville: University of Florida Institute of Food and Agricultural Sciences.

Maynard, D. N. 1992. "Watermelon Varieties.” In Watermelon Production Guide for Florida, edited by D. N. Maynard, 3-4. Gainesville: University of Florida Institute of Food and Agricultural Sciences.

Maynard, D. N., and D. L. Hopkins. 1999. "Watermelon Fruit Disorders.” HortTechnology 9 (2): 155-161.

McSorley, R. 1999. "Nonchemical Management of PlantParasitic Nematodes." The IPM Practitioner 21 (2): 1-7.

Miller, J. F., A. D. Worsham, L. L. McCormick, D. E. Davis, R. Cofer, and J. A. Smith. 1975. Weeds of the Southern United States. Gainesville: University of Florida Institute of Food and Agricultural Sciences.

Mitchell, D. J., F. N. Martin, and R. Charudattan. 1994. "Biological Control of Plant Pathogens and Weeds in Florida." In Pest Management in the Subtropics, Biological 
Control: A Florida Perspective, edited by D. Rosen, F. D. Bennett, and J. L. Capinera, 549-574. Andover, UK; Intercept.

Nguyen, K. B., and G. C. Smart, Jr. 1990. "Steinernema scapterisci n.sp. (Rhabditida: Steinernematidae)." Journal of Nematology 22 (2): 187-199.

Noling, J. W. and J. P. Gilreath. 1999. "Alternatives to Methyl Bromide for Nematode Control: A South Florida Synopsis." Proceedings of the 1998 Annual International Research Conference on Methyl Bromide Alternatives and Emissions Reductions. December 7-9, 1998, Orlando, Florida.

Noling, J.W. 2012a. Nematode Management in Cucurbits (Cucumber, Melons, Squash). ENY-025. Gainesville: University of Florida Institute of Food and Agricultural Sciences. http://edis.ifas.ufl.edu/ng025.

Noling, J.W. 2012b. Nematodes and Their Management. ENY625. Gainesville: University of Florida Institute of Food and Agricultural Sciences. http://edis.ifas.ufl.edu/cv112.

Noling, J. W. 2013. Nematologist, UF/IFAS Citrus Research and Education Center, in communication with the author.

Norman, J. W., Jr., D. G. Riley, P. A. Stansly, P. C. Ellsworth, and N. C. Toscano. 1993. Management of Silverleaf Whitefly: A Comprehensive Manual on the Biology, Economic Impact and Control Tactics. Washington, DC: USDA/CSREES.

Nuessly, G. S., and M. Hentz. 1998. EREC Moth Pheromone Trap Data. Gainesville: University of Florida Institute of Food and Agricultural Sciences.

Olson, S. M., P. J. Dittmar, P. D. Roberts, S. E. Webb, and S. A. Smith. 2012. Cucurbit Production in Florida. HS725. Gainesville: University of Florida Institute of Food and Agricultural Sciences. http://edis.ifas.ufl.edu/cv123.

Purcifull, D. E., W. C. Adlerz, G. W. Simone, E. Hiebert, and S. R. Christie. 1984. "Serological Relationships and Partial Characterization of Zucchini Yellow Mosaic Virus Isolated from Squash in Florida." Plant Disease 68: 230-233.

Roberts, P., and T. Kucharek. 2005. 2006 Florida Plant Disease Management Guide: Watermelon. PDMG-V3-55. Gainesville: University of Florida Institute of Food and Agricultural Sciences. http://gcrec.ifas.ufl.edu/watermelons/ diseases/diseases.htm
Roberts, P. D., and R. J. McGovern. 1998. "Phytophthora Blight Causes Significant Losses to Spring Vegetable Crops." Citrus \& Vegetable Magazine 62 (11): 8-11.

Rushing, J. W. 2004. "Watermelon.” In The Commercial Storage of Fruits, Vegetables, and Florist \& Nursery Crops, 3rd edition, edited by K. Gross and M. Saltveit. USDA Handbook 66. Washington, DC: USDA/ARS. www.ba.ars. usda.gov/hb66/contents.html.

Sakimura, K., L. M. Nakahara, and H. A. Denmark. 1986. A Thrips, Thrips palmi Karny (Thysanoptera: Thripidae). Entomology Circular No. 280. Gainesville, FL: FDACS Division of Plant Industry.

Sanford, M. T., and J. Ellis. 2011. Beekeeping: Watermelon Pollination. ENY-154. Gainesville: University of Florida Institute of Food and Agricultural Sciences. http://edis.ifas. ufl.edu/aa091.

Sargent, S. A. 1992. "Harvesting and Handling Watermelons." In Watermelon Production Guide for Florida, edited by D. N. Maynard. SP-113. Gainesville: University of Florida Institute of Food and Agricultural Sciences.

Schuster, D. J., and J. F. Price. 1992. "Seedling Feeding Damage and Preference of Scapteriscus spp. Mole Crickets (Orthoptera: Gryllotalpidae) Associated with Horticultural Crops in West-Central Florida." Florida Entomologist 75 (1): 115-119.

Smith, S. A., and T. G. Taylor. 2011. Production Costs and Commodity Budgets for Selected Florida Vegetables. FE436. Gainesville: University of Florida Institute of Food and Agricultural Sciences. http://edis.ifas.ufl.edu/fe436.

Somodi, G. C., J. B. Jones, D. L. Hopkins, R. E. Stall, T. A. Kucharek, N. C. Hodge, and J. C. Watterson. 1991. "Occurrence of a Bacterial Watermelon Fruit Blotch in Florida." Plant Disease 75: 1053-1056.

South, L. 1991. "New Thrips Threatens South Florida." American Vegetable Grower 39 (5): 30.

Spreen, T. H., J. J. VanSickle, A. E. Moseley, M. S. Deepak, and L. Mathers. 1995. Use of Methyl Bromide and the Economic Impact of Its Proposed Ban on the Florida Fruit and Vegetable Industry. Gainesville: University of Florida Institute of Food and Agricultural Sciences.

Stall, W. 1999. "Watermelon Weed Control." Citrus \& Vegetable Magazine 63 (7): 30-34. 
Stall, W. M. 1992. “Weed Management.” In Watermelon Production Guide for Florida, edited by D. N. Maynard, 45-46. SP-113. Gainesville: University of Florida Institute of Food and Agricultural Sciences.

Stansly, P. A. 2011. Insects That Affect Vegetable Crops. ENY450. Gainesville: University of Florida Institute of Food and Agricultural Sciences. http://edis.ifas.ufl.edu/cv111.

Stansly, P. A. 1995. "Seasonal Abundance of Silverleaf Whitefly in Southwest Florida Vegetable Fields." Proceedings of the Florida State Horticultural Society 108: 234-242.

Stephens, J. M. 2012. Watermelon, Seedless - Citrullus lanatus (Thunb.) Mansf. HS685. Gainesville: University of Florida Institute of Food and Agricultural Sciences. http:// edis.ifas.ufl.edu/mv152.

Stokes, D. E. 1972. Root-Knot Nematodes (Meloidogyne spp.). Nematology Circular No. 11. Gainesville, FL: FDACS, Division of Plant Industry.

Terry, E.R., Jr., W. M. Stall, D. G. Shilling, T. A. Bewick, and S. R. Kostewicz. 1997. "Smooth Amaranth Inference with Watermelon and Muskmelon Production." HortScience 32 (4): 630-632.

Tsai, J. H., B. Yue, S. E. Webb, J. E. Funderburk, and H. T. Hsu. 1995. "Effects of Host Plant and Temperature on Growth and Reproduction of Thrips palmi (Thysanoptera: Thripidae)." Environmental Entomology 24 (6): 1598-1603.

U.S. Department of Agriculture National Agricultural Statistics Service (USDA/NASS). 2011a. Agricultural Statistics Annual. Washington, D.C.: USDA/NASS. http://www.nass. usda.gov/Publications/Ag_Statistics/2011/index.asp.

USDA/NASS. 2011b. Agricultural Chemical Usage, Vegetables. Agriculture Marketing Service. Washington, DC: USDA/NASS. http://usda.mannlib.cornell.edu/MannUsda/ viewDocumentInfo.do?documentID $=1561$.

USDA/NASS. 2011c. Quick Statistics. Washington, DC: USDA/NASS. http://www.nass.usda.gov/Statistics_by_ State/Florida/index.asp.

USDA/NASS. 2009. 2007 Census of Agriculture, Florida State and County Data. Washington, D.C.: USDA/NASS. http://www.agcensus.usda.gov/Publications/2007/Full_Report/Volume_1,_Chapter_1_State_Level/Florida/flv1.pdf.
Vallad, G., K. Pernezny, N. Peres, R. Raid, P. Roberts, and S. Zhang. 2010. 2010 Florida Plant Disease Management Guide: Chemical Control Guide for Diseases of Vegetables, Revision No. 21. PPP6. Gainesville: University of Florida Institute of Food and Agriculture Sciences.

Vavrina, C. S. 1992. "Watermelon Transplants." In Watermelon Production Guide for Florida, edited by D. N. Maynard. SP-113. Gainesville: University of Florida Institute of Food and Agricultural Sciences.

Watson, J. R., and A. N. Tissot. 1942. Insects and Other Pests of Florida Vegetables. Bulletin 370. Gainesville: University of Florida, Florida Agricultural Experiment Station. 